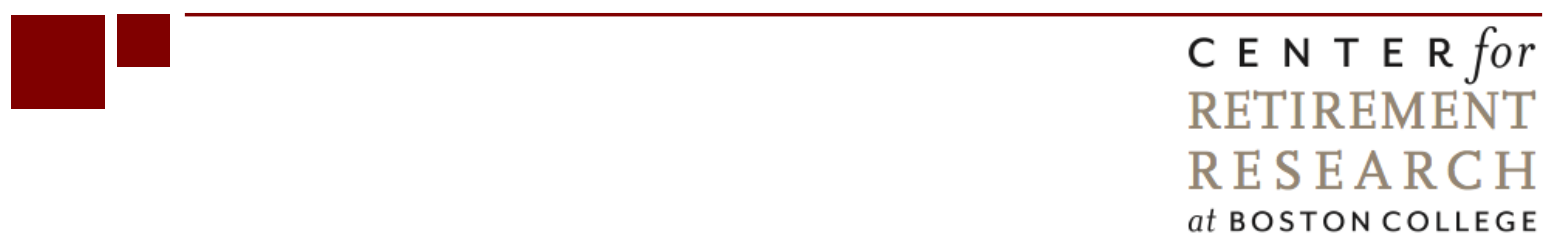

\title{
WILL DELAYED RETIREMENT BY THE BABY BOOMERS LEAD TO HIGHER UNEMPLOYMENT AMONG YOUNGER WORKERS?
}

\author{
Alicia H. Munnell and April Yanyuan Wu \\ CRR WP 2012-22 \\ Original version released: October 2012 \\ Expanded version released: October 2013 \\ Center for Retirement Research at Boston College \\ Hovey House \\ 140 Commonwealth Avenue \\ Chestnut Hill, MA 02467 \\ Tel: 617-552-1762 Fax: 617-552-0191 \\ http://crr.bc.edu
}

Alicia H. Munnell is the director of the Center for Retirement Research at Boston College (CRR) and the Peter F. Drucker Professor of Management Sciences at Boston College's Carroll School of Management. April Yanyuan Wu is a research economist at the CRR. The research reported here was performed pursuant to a grant from The Pew Charitable Trusts. The opinions and conclusion expressed are solely those of the authors and do not represent the opinions or policy of Pew Charitable Trusts or Boston College. The authors would like to thank Laura Quinby and Kara Bradley for excellent research assistance. The authors would also like to thank Norma B. Coe, Matthew S. Rutledge, and Anthony Webb for their comments.

(C) 2012, by Alicia H. Munnell and April Yanyuan Wu. All rights reserved. Short sections of text, not to exceed two paragraphs, may be quoted without explicit permission provided that full credit, including $(\mathrm{C}$ notice, is given to the source. 
About the Center for Retirement Research

The Center for Retirement Research at Boston College, part of a consortium that includes parallel centers at the University of Michigan and the National Bureau of Economic Research, was established in 1998 through a grant from the Social Security Administration. The Center's mission is to produce first-class research and forge a strong link between the academic community and decision-makers in the public and private sectors around an issue of critical importance to the nation's future. To achieve this mission, the Center sponsors a wide variety of research projects, transmits new findings to a broad audience, trains new scholars, and broadens access to valuable data sources.

Center for Retirement Research at Boston College

Hovey House

140 Commonwealth Avenue

Chestnut Hill, MA 02467

phone: 617-552-1762 fax: 617-552-0191

e-mail: crr@bc.edu

crr.bc.edu

Affiliated Institutions:

The Brookings Institution

Massachusetts Institute of Technology

Syracuse University

Urban Institute 


\begin{abstract}
This paper investigates the oft-repeated claim that delayed retirement by older workers will result in higher unemployment among the young, a claim which has garnered increased attention in the media in the United States and which drives retirement policy in China. Using 1977-2011 data from the Current Population Survey (CPS), the analysis explores both timeseries and cross-state variation, and employs state-level regressions and instrumental-variable models to determine the extent to which such "crowding out" exists in the United States. The estimates show no evidence that increasing the employment of older persons reduces either the job opportunities or wage rates of younger persons. The patterns are consistent for both men and women and for groups with different levels of education. Estimates using older male mortality rates as instrumental variables also produce no consistent evidence that changes in employment rates of older people adversely affect the employment (both intensive and extensive margins) and wage rates of their younger counterparts. If anything, the opposite is true. Despite the fact that the labor market downturn that accompanied the Great Recession was the most severe experienced in the post-war era, the effects of older persons' employment on other segments of the labor market do not differ from those during typical business cycles. Finally, the analysis of Chinese data also finds that the employment of older people has no impact on labor market outcomes for other age groups.
\end{abstract}




\section{Introduction}

Between December 2007 and May 2010, the employment rate dropped by 6 percentage points for men ages 25-54, but less than 3 percentage points for workers age 55 and older. The pattern for women was equally dramatic: the employment rate dropped by 3 percentage points for younger women and actually increased slightly for older women (U.S. Bureau of Labor Statistics, 2007-2010). These strikingly divergent labor force patterns between the old and the young generated widespread media claims that delayed retirement by the baby boomers causes higher unemployment among the young. ${ }^{1}$

The proposition that more work by older persons reduces the job opportunities for younger persons is known as the "lump of labor theory." This notion is widely accepted in many European countries and has provided an economic rationale for early retirement programs. In the United States, economists generally reject the lump of labor theory, arguing that the labor market is dynamic and that the economy can adapt to labor force changes. Nevertheless, the increased media attention and its potential influence on public policy calls for an empirical analysis.

As life expectancy increases and the retirement income system contracts, households face an enormous challenge in ensuring a secure retirement. Working longer is often hailed as the best way to increase retirement incomes (Munnell and Sass 2008). On the other hand, the ability to climb onto the first rungs of the career ladder is critical for the young; it significantly impacts their lifetime earnings and upward mobility. Therefore, understanding the relationship between older and younger persons' labor force behavior is crucial both for evaluating provisions introduced to encourage work among older Americans and for helping policymakers understand how best to improve economic opportunity among the young.

This paper uses data from the Current Population Survey (CPS) over the period 19772011 to test the lump of labor theory. The analysis focuses on variations across and within states

\footnotetext{
${ }^{1}$ Reuters has reported that young adults in the United States are being squeezed out of the labor force as older workers either delay retirement or seek jobs to rebuild nest eggs destroyed by the recession (Mutikani, 2010). Similar arguments appeared in The New York Times, U.S. News \& World Report, Time, Bloomberg, CNN Money, Insurance Journal, and other major media. The New York Times claimed that the delay of seniors' retirement has made it more difficult for millions of young workers to climb onto the first rung or two of the career ladder, lowering their lifetime earnings for impeding their upward mobility (see Greenhouse 2009; Brandon 2009; Valetkevitch 2010; Dickler 2010; Cinko, McDonough, and Schlisserman 2010; Gandel 2010 for a few examples).
} 
to see if greater labor force participation by older people hurts younger people in terms of their employment rates, hours worked, or wages. Additionally, this study looks for heterogeneous effects based on educational attainment, because groups with similar skills can be more easily substituted. And because labor market conditions may impact the labor supply and earnings of both older and younger persons simultaneously, the analysis includes an Instrumental Variables (IV) approach, using mortality rates for older people as instruments, to identify the causal mechanism. Further, the study pays special attention to the 2008 financial collapse to determine whether the relationship between employment and wage patterns of the young and old changed during the Great Recession. Finally, because the lump of labor theory drives retirement policies in China, we repeat the analysis using available Chinese data.

The paper proceeds as follows. Section 2 summarizes the "lump of labor" debate in the economics literature. Section 3 describes the data and explores time-series and cross-state trends of labor supply across different age groups for the United States. Section 4 presents the model, outlines the empirical strategies, and discusses the evidence on "crowd out." Section 5 introduces an instrumental variables approach to identify causality in the reported relationships. Section 6 investigates the relationship between older and younger persons' labor force behavior in China. The final section concludes.

Our estimates find no evidence that increasing the employment of older persons reduces the job opportunities or wage rates of young persons in either the United States or China. The patterns are consistent for both men and women and for groups with different levels of education. Estimates using instrumental variables also produce no consistent evidence that changes in employment rates for older people adversely affect the employment and wage rates of their younger counterparts. If anything, the opposite is true. Finally, despite the fact that the labor market downturn that accompanied the Great Recession was the most severe experienced in the post-war era, the effects of older persons' employment on other segments of the labor market do not differ from those during typical business cycles.

\section{Background}

The Lump of Labor Theory. The "lump of labor" theory can be traced to Henry Mayhew' s 1851 London Labour and the London Poor. Mayhew argued that cutting the 
number of hours employees worked would reduce unemployment. Starting with David Schloss in 1891, economists have repeatedly characterized this argument as a fallacy.

The fallacy of the lump of labor theory rests on the supposition that the number of jobs is limited. As Samuelson argues in his textbook, Economics, "It is more correct to say that an economy can adjust to create jobs for willing workers. In the long run, as prices and wages adjust to change in technology and tastes, to supplies and demands, jobs will come to workers or workers will move to jobs."

Despite the skepticism of economists, opponents of free trade, technological advance, and immigration often use the lump of labor argument to make people fearful about losing their jobs. They ignore the fact that, over the long run, technological improvements create new products and services, raise national income, and increase demand for labor throughout the economy. They also fail to acknowledge that job opportunities rise with a growing population as immigrants enter the market as consumers as well as workers.

The criticism of the lump of labor theory focuses on long-run market adjustments. It might be true that this argument holds in the very short run or during prolonged periods of stagnation, such as the Great Recession.

Literature Review. The "lump of labor" argument frequently appears in immigration and early retirement literature, as it is often claimed that immigrant workers take jobs away from native workers and that fewer older people in the labor force would open up more job opportunities for the young.

An extensive literature has examined the impact of immigration on the employment of native workers (see Fetter 1913, Greenwood and McDowell 1986, Borjas 2006; Card 2001, 2005 for a few examples). While relying on different datasets and methodologies, and examining different time periods, none of these studies finds evidence that immigrants crowd out natives. Similarly, research exploiting the large variation in immigrant flows across U.S. states reports little crowding out of hours between immigrants and natives (Peri 2009). And an analysis of the impact of increased immigration on the earnings of workers who are close substitutes for 
immigrants concludes that immigrants are easily absorbed by the U.S. labor market, with only minor effects on native workers (LaLonde and Topel 1989). ${ }^{2}$

The literature on the relationship between the labor-force participation of younger and older individuals is relatively small. A series of papers examines whether employment of older individuals crowds out employment of younger individuals in 12 countries (Gruber and Wise 2010). Based on individual country and cross-country analyses, none of these international studies finds evidence that increasing the labor-force participation of older people reduces the job opportunities of younger people. Indeed, the evidence suggests that greater labor-force participation of older people is associated with greater youth employment and reduced youth unemployment. ${ }^{3}$ Particularly relevant to this paper is the study in a volume by Gruber and Milligan (2008) that investigates the extent of this "crowding out" in the United States from 1962 through 2007 and finds little substitution between the young and the old.

Gruber and Milligan cannot be considered the last word, however. The authors are constrained to methods and data that could be applied to all 12 countries for ease of comparison. Further, they measure the impact of older persons' labor force participation only on employment of younger people and ignore any potential impact on hours worked or wages. Moreover the period they examine was before the Great Recession.

This paper builds on Gruber and Milligan (2008) for the U.S. analysis. The study investigates the potential "crowding-out" at both extensive and intensive margins, and examines not only the effect of more older workers on the "quantity" of younger workers but also on their "price" - their wage. The paper also pays special attention to the impact of the Great Recession, which could have a different effect than would be observed during typical business cycles. Further, this paper makes use of IV methods to identify the causal mechanism between the labor supply of older and younger workers. Finally, the paper uses Chinese data to examine whether the relationship may differ in developing countries.

\footnotetext{
${ }^{2}$ The empirical literature on how wages adjusting to an immigrant-induced labor supply shift fails to reach a consensus. Some studies claim that immigration has a substantial impact on wages in receiving and sending countries (e.g.,Borjas 2003; Mishra 2007), while other studies claim the impact is negligible (Card 2005; Ottaviano and Peri 2008).

${ }^{3}$ One possible explanation for this positive relationship is suggested by Van Dalen and Henkens (2002), who focus on the relationship between financing early retirement and labor demand. The authors find that when early retirement schemes are financed through payroll taxes, wage costs for all workers may increase, thereby reducing the total labor demand. As a result, the employment of the young and the elderly would be positively related.
} 


\section{Data and Sample for the United States}

Our analysis of the labor market impacts of older persons' labor-force participation uses data from the March supplement of the Current Population Survey (CPS). The survey includes detailed questions about labor force participation, wages and salaries, and income from various sources. The survey also includes rich demographic information as well as information about the individual's health and work disability status. The analysis spans 1977 through 2011, which includes the Great Recession. ${ }^{4}$

The analytic sample, which consists of individuals aged 20 to 64 in the survey year, is divided into three age groups: 20-24 (the "young"), 25-54 (the "prime-aged"), and 55-64 (the "old"), to be consistent with the literature. The variables of interest include labor force participation, employment and unemployment rates, hours worked last week, and wage rates. ${ }^{5}$ The average of each measure for each age group is calculated over time using the provided survey weights.

The substantial spatial variation in labor supply in the United States has been documented in the economic geography literature (for example, Odland and Ellis 1998 and Ward and Dale 1992). The cross-state/MSA variation in labor supply, which is as large as the widely studied variation across OECD countries, has recently drawn increased attention by economists (see Black et al. 2009, Munnell et al. 2008, Pollack 2010 for a few examples). These variations afford an unexplored and potentially fruitful avenue to measure the impact of older persons' employment on younger ones.

The variation across states is striking. In 2011, the employment rates of older persons vary from 44 percent in Louisiana to 80 percent in North Dakota (Table 1.1). Similarly wide variation is evident in other years as well. Older persons' labor supply also varies substantially over time within a state. For example, from 1977 through 2011, the employment rate increases by 15 percentage points in Connecticut, but decreases by 6 percentage points in Louisiana.

Similar data for the young and prime-aged are shown in Tables 1.2 and 1.3. In each case, the differences in employment rates across states are large. For example, in 2011, employment

\footnotetext{
4 The March CPS does not include state identifiers before 1977. Data for employment status are missing from 1994. The year refers to the survey year rather than calendar year.

${ }^{5}$ The labor force participation rate is defined as a percent of the civilian non-institutional population. The employment rate represents the share of the population over age 16 who work. The unemployment rate represents the number unemployed as a percent of the labor force.
} 
rates for the young vary from 48 percent (South Carolina) to 76 percent (Nebraska). The corresponding range for the prime-aged is 66 percent (West Virginia) to 86 percent (North Dakota). The variation in hours worked per week is equally large. In 2011, this measure of labor supply for older persons ranges from 20.3 hours worked per week last year (Louisiana) to 35.5 hours (North Dakota).

\section{Direct Evidence on the Effect of Crowd-out}

Model Specifications. This section makes use of the substantial spatial variation in labor supply to formally investigate the relationship between employment outcomes for the old and young. The basic model is of the form:

$$
Y_{s t}=\beta_{0}+\beta_{1} \text { olderemp }_{s t}+X_{s t} \beta_{2}+\gamma_{t}+\delta \operatorname{Rec}+\Psi_{s}+\varepsilon_{s t}
$$

where $Y_{s t}$ is the outcome of interest for state $s$ in year $t$, such as employment and unemployment rates, hours worked, and the average wage rate and earnings of young and prime-aged individuals. The key independent variable in the regression is the state-year employment rate of older people $\left(\right.$ Olderemp $\left._{s t}\right)$. The vector $X_{s t}$ includes a set of state-specific, time-varying explanatory variables. These include differences in labor market conditions (such as the percapita level of Gross State Product (GSP), GSP growth, the state average unemployment rate, the state poverty rate, and the age structure of the population), the nature of employment (the concentration of manufacturing, the concentration of the service industry, and the share of selfemployment), and the state's demographic characteristics (such as the share of low educated and race composition). ${ }^{6}$ The equation also includes a measure of the state housing price index. The regression of employment and unemployment rates also controls for local wages for the specific age group. $\gamma_{t}$ is a set of indicator variables for years 1977-2011 to control for nationwide economic changes in any given year. Additionally, the equation includes an indicator variable, $R e c$, for the Great Recession, to capture the differential impact of the economic downturn on

\footnotetext{
${ }^{6}$ The state unemployment rate is excluded from the model when outcome variables are age-specific unemployment/employment rates by state, due to a high degree of collinearity.
} 
labor supply. ${ }^{7} \psi_{s}$ represents a set of state controls. Including state controls in the equation isolates the effects of changing economic conditions on labor force participation from the largely structural influences that vary across states. The price of this approach is that the variation tends to be less dramatic than the differences across states. Fortunately, as highlighted in Table 2, Column (5), the within-state deviation in most of the variables is substantial.

Table 2 presents the descriptive statistics of the data. These statistics reflect 1785 statelevel observations for 50 states plus Washington D.C. from 1977-2011, with a few exceptions due to data limitations. ${ }^{8}$ On average, the unemployment rate of the young is 11 percent, but ranges from 6 percent to 17 percent. The within-state variation is even larger. The average unemployment rate of the prime-aged is lower (at 5 percent) with a smaller variance. The average employment rate for the young, the prime-aged, and the old is 67, 78, and 57 percent, respectively. Both the unemployment and employment rates are higher for men compared to women. Not surprisingly, the typical prime-aged adult works more hours per week (34 hours) than the young and earns a higher hourly wage $(\$ 20$ per hour) and annual income $(\$ 31,000)$ than the young.

Demographic characteristics also vary considerably among states. For example, the share of the population ages 20-24 is 11 percent on average, but varies between 9 and 15 percent. The share of high school and less population (among age 18 and above) varies between 43 and 70 percent. The fraction of blacks varies between 0 and 66 percent. Between 3 percent and 26 percent of the state is employed in manufacturing jobs, and between 6 and 18 percent is selfemployed.

\section{The "crowding out" effect on quantity: labor force participation and hours worked.} Table 3.1 displays the Ordinary Least Square (OLS) regression results of equation (1) for men and women pooled together. The first column has the results for youth unemployment. If crowding out were occurring, an increase in older persons' employment would increase youth

\footnotetext{
7 The Recession dummy is constructed as equal to zero if before 2008 and 1 after 2008, which is not perfectly collinear with year dummies.

${ }^{8}$ The sample size becomes small when we break down data to state-year-age-gender cells. Some estimates appear unreliable due to limited sample size. Since including an unreliable value may give invalid results, we exclude the top 1 percent and the bottom 1 percent of observations of outcome variables in our state-year-age-gender regressions.
} 
unemployment. However, the coefficient is negative and statistically insignificant, that is the increase in the employment rate for older people has no impact on youth unemployment. The second column presents the results for youth employment. Again, no sign of crowd out is evident. Instead, a 1-percentage-point increase in the employment rate for older people is associated with a 0.07 percentage points increase in youth employment. This finding strongly contradicts the crowd-out hypothesis.

In addition to employment/unemployment, equations are also estimated to measure the impact of the employment rate among older people on hours worked by the young. The results are summarized in the third column of Table 3.1. Again, the results show no evidence of crowding out in terms of the extensive margin of labor supply: the coefficient is positive (0.05) and statistically insignificant.

Table 3.1 also presents the results for prime-aged individuals. The pattern that emerges is the same as for the young: instead of crowding out, employment of older people has no effect on unemployment or hours worked by the prime-age, but significantly increases their employment.

Most of the other controls have coefficients in the expected direction, albeit often insignificant. Consistent with the literature, the state poverty level increases state-level youth unemployment and high housing prices and the share of jobs in self-employment reduce statelevel youth unemployment. An increasing proportion of manufacturing job is associated with an increase in employment for both the young and the prime-aged, likely reflecting job opportunities for low-skilled workers. At the same time, self-employment is negatively associated with youth employment and hours worked. In addition, more service jobs leads to a reduction in hours worked by both the young and the prime-aged; this is expected as jobs in these industries are more likely to be part-time or have flexible hours. Finally, not surprisingly, the Great Recession strongly negatively impacts the labor market behaviors of both the young and prime-aged.

Two control variables have different impacts on the young and the prime aged. First, a higher share of same-age population increases the hours worked by the young but has no impact on the prime-aged. The positive coefficient suggests an endogenous migration story: workers move to the states with better job prospects for their age group. It appears that endogenous migration plays a stronger role for the young than for the prime-aged. Second, a higher local average wage has little impact for the young but is associated with increased unemployment and 
decreased employment for the prime-aged. This relationship can occur if large labor market exits occur from the bottom of the income distribution during recessions. ${ }^{9}$

To account for the secular upward trend in female labor supply over time, separate results for men and women are shown in Tables 3.2. ${ }^{10}$ These results are largely consistent with the aggregate analysis. The magnitudes of the coefficients on employment of older persons are sometimes higher and sometimes lower, and significance fails in some cases. However, for both the males and females, the results show no evidence of a crowd-out. If anything, employment of the old is positively associated with employment of the young and the prime-aged. ${ }^{11}$

The "crowding out" effect on price: wage rates. In addition to exploring the effect of older workers on the "quantity" of younger workers, regressions are estimated to examine the effect on the "price" of younger workers - that is, their wages. If crowd-out of the young by the old does exist, younger workers may confront reduced earnings due to an increased labor supply of older people. Two measures of "price" are used: log hourly wage and log annual income. The explanatory variables are the same as in the earlier equations.

The results are shown in Table 4.1. Instead of a negative correlation between employment of the old and the "price" of younger workers, the results again show some positive impacts, though the impact on the hourly wage of the young is not statistically significant and the impact on annual income of the young is only significant at 10 percent level. We also find that employment of older people has significant impacts on the hourly wage and annual income of the prime-aged: a 1-percentage-point increase in older persons' employment rate is predicted to increase the hourly wage rate of the prime-aged by 0.08 percent and the annual income of these workers by 0.11 percent. The coefficients on the other controls are largely consistent with those of the "quantity" analysis.

\footnotetext{
${ }^{9}$ For the young, real wages have displayed a modest cyclicality (see Lucas 1977, Mankiw 1989, and Blanchard and Fischer 1989 for a few examples). In contrast, a selection story is more likely for prime-aged workers: while the measure of wages is constructed as the average of non-zero wages, a countercyclical impact is possible if there is a large increase in labor force exit, particularly from the bottom of the wage distribution (Solon, Barsky, and Parker, 1994).

${ }^{10}$ Table 3.2 presents selected coefficient estimates. The full regression results are available upon request from the authors.

${ }^{11}$ We also estimated equations excluding the wage controls to address concerns that wages are endogenous. The results are summarized in Appendix Table 1. The coefficients are largely consistent.
} 
A few findings are worth a comment. First, an increasing proportion of high-school and less educated individuals is associated with declines in the hourly wage and annual income of both young and prime-aged workers, reflecting returns to education. Second, while the increasing prevalence of self-employment jobs is related to declines in annual income for both young and prime-aged workers, it is positively correlated with hourly wages for the prime-aged. This finding is consistent with the literature, which finds that the self-employed on average have lower initial earnings and earnings growth than their counterparts (Hamilton 2000). On the other hand, given the fact that self-employed jobs are more likely to be part-time, flexible hours and to have less generous fringe benefits, a higher hourly wage rate seems reasonable. In addition, an increase in the share in manufacturing is related to a decline in the hourly wage rate, probably due to employee characteristics - low-skilled workers are concentrated in manufacturing.

Table 4.2 breaks out the results for men and women, respectively. ${ }^{12}$ The results are largely consistent with those of the aggregated analysis. For men, two of the four coefficients are positive and statistically significant. For women, one of the four is positive and significant. The message is clear: no evidence supports the contention that the employment of the old reduces the wages of the young.

Does the relationship differ during the Great Recession? The Great Recession is generally acknowledged to be the worst downturn since the Great Depression, resulting in a dramatic increase in unemployment. While a fundamental flaw underlying the lump-of-labor theory is that it ignores long-run labor market adjustments, short-run effects could be differ from long-run effects. That is, when employment overall is dropping, crowd-out between different groups might be possible.

We estimate a specification where all variables in $X_{s t}$ are interacted with $R e c$, to allow for the differential impact of the Great Recession on labor market behaviors:

$Y_{s t}=\beta_{0}+\beta_{1}$ Olderemp $_{s t}+\beta_{2}$ Olderemp $_{s t} \operatorname{Rec}+\delta$ Rec $+X_{s t} \beta_{3}+\beta_{4} X_{s t} \operatorname{Rec}+\gamma_{t}+\Psi_{s}+\varepsilon_{s t}$ (2)

\footnotetext{
12 Table 4.2 presents selected coefficient estimates. The full regression results are available upon request from the authors.
} 
The results are shown in Table 5.1. If older persons' employment were affecting the unemployment rates of the young during the Great Recession, the coefficient of the interaction term should be positive and statistically significant. Instead, it is insignificant. The pattern holds for employment and hours worked. For the young, the only evidence that the relationship changes during the Great Recession contradicts the crowd-out hypothesis. During the Great Recession, a 1-percentage-point increase in the employment rate for older people is associated with an increase hourly wage rate of the young by an additional 0.28 percent compared to the typical business cycle.

Similar patterns emerge for the prime-aged - negative effects for the unemployment rate and positive associations for employment and hours worked during the Great Recession compared to the period before. The only evidence that is consistent with the crowd-out hypothesis pertains to the wage rate estimation of the full interaction model: while a 1percentage-point increase in employment among older Americans is associated with a 0.09 percent increase in the wage rate in the typical business cycle, the impact becomes a 0.20 percent decrease in the Great Recession.

The results by gender (Table 5.2) are largely consistent. ${ }^{13}$ For men, the estimates provide no evidence of any crowding out during the Great Recession. Instead, during the Great Recession, employment of older men has an even more positive impact on the various labor market outcomes of younger men. For women, the results provide some indication of crowd-out: increasing employment of older females is associated with declines in the wage rates of primeaged females and increases in unemployment of young females.

Most of the estimated coefficients for the control variables interacted with the Great Recession are in the expected direction. A few estimates are worth commenting on. First, while an increasing share of jobs in manufacturing is generally associated with an increase in employment of both the young and the prime-aged, this effect declines and even becomes negative during the Great Recession. Since manufacturing jobs tend to be concentrated among low-skilled workers, and young workers are more likely to be low-skilled, the cyclicality of these jobs may help explain why the young are hardest hit by the Great Recession. Second, during the

\footnotetext{
${ }^{13}$ Table 5.2 presents selected coefficient estimates. The full regression results are available upon request from the authors.
} 
Great Recession, real wages for the young are positively correlated with their unemployment, probably suggesting a large exit of the low-paid young from the labor market.

Differential impacts by education groups. The potential for older workers to crowd out younger ones should depend on the extent to which they are substitutes. Economic theory suggests that the more similar the groups are with respect to skills, the greater the degree of substitution. Therefore, this section explores whether the effects are different by education groups. Table 6.1 summarizes the results for those with high-school-and-less education. For the young, the coefficients of older persons' employment, with one exception, are statistically insignificant. The only significant estimate suggests that more low-educated elderly employment leads to an increase in employment of low-educated young persons. For the prime-aged, the message is again that employment among older people has no effect on labor market outcomes for the prime-aged.

Table 6.2 displays the results for those with college-and-above. Again, the results provide no support for the crowd-out hypothesis. In short, the relationship between older and younger persons' labor-force behavior does not vary by educational attainment.

Sensitivity Tests. This section tests the robustness of the state-fixed effects findings in three ways. First, to avoid the impact of any contemporary shock affecting both sides of the equation, the labor supply behavior and wage rates of youth and prime-age persons in a given year are regressed on the employment of older persons three years earlier. Second, to account for the fact that large and small states are given equal weight in the analysis, which could produce inefficient estimates of coefficients, the equations are re-estimated using a feasible Generalized Least Squares (GLS) procedure. Third, to address the potential problem of limited size when breaking down data to state-year-age cells, the data are pooled across three-years to maintain an adequate sample size.

The results of the sensitivity tests are summarized in Table 7. Each cell reports the coefficient for older persons' employment from a separate regression. The estimations across different specifications are largely consistent with the results reported earlier, with the magnitude of coefficients from the pooled-three-year model being generally larger. Looking at the unemployment rate of the young in the first column, the coefficients down the column are 
negative and none is statistically significant. In terms of employment shown in the second column, more elderly employment leads to an increase in youth employment, with three of the four coefficients being significant at 5 percent level. The same pattern emerges as for the primeaged, the males, and the females. None of the results support the crowd-out hypothesis.

\section{Instrumental Variable Approach}

Instrumental Variable. Even when controlling for the various determinants of general unemployment, the approach described in the previous section is difficult to interpret in terms of a causal impact of older persons' employment on the labor-force activity of younger workers. If some unobserved factors have simultaneous impacts on the unemployment of younger workers and on the labor-force participation of older people, then an endogeneity problem can arise. For instance, a positive technology or investment shock in a state may simultaneously boost employment for both old and young. In such cases, OLS would be biased towards a positive value. To address this problem and to obtain unbiased estimates, the following analysis employs an instrumental variable approach.

The goal is to identify an instrumental variable that 1) is correlated with employment for older people (instrument relevance) and 2) has no direct impact on the employment of the younger cohort (exclusion restriction). State-year-age specific mortality rates satisfy both criteria. The association between individuals' employment behavior and their health status are well-established in the literature. For instance, involuntary retirements are often due to negative health shocks (Haider and Stephens 2007; Smith 2006; Hurd and Rohwedder 2003, 2008), and poor health status among older workers is strongly correlated with early exit from the labor market (McGarry 2004). The own-age group mortality rate has been widely suggested to be strongly associated with one's own group health status and, thus, it is related to own-group employment. Further, Stevens et al. (2011) report that own-group mortality is negatively correlated with one's own group employment rate. 
Moreover, the literature offers little support that one group's mortality is related to another group's employment. ${ }^{14}$ For instance, Stevens et al. (2011) provide some evidence on the independence of older mortality rates and the work status of younger workers. ${ }^{15,16}$

The measure of the mortality rate is based on death counts from Vital Statistics publications. The data, which are available from 1979-2008, are used to construct state-level death counts by age and sex.

IV Estimates. Once the instrumental variable is constructed, the next step is to estimate a Two Stage Least Squares (TSLS) model. The first stage estimates the effect of state-year mortality rates on the employment rate of older people, Olderemp, using the following model:

$$
\text { Olderemp }_{s t}=a_{0}+a_{1} M T_{s t}+X_{s t} \beta_{2}+\gamma_{t}+\Psi_{s}+\varepsilon_{s t}
$$

As opposed to using the mortality rates of all individuals, ages 55-64, we use the mortality rates of men, ages 55-64, for larger variation across state over time. Thus, $M T_{s t}$ represents the natural $\log$ of the mortality rate in state $s$ and year $t$ of the men in this age group.

In the second stage, the predicted value of older persons' employment from the first stage is substituted for actual older persons' employment:

$$
Y_{s t}=\beta_{0}+\beta_{1} \text { Old } \widehat{\text { erem }} p_{s t}+X_{s t} \beta_{2}+\gamma_{t}+\Psi_{s}+\varepsilon_{s t}
$$

Where Old $\widehat{\text { erem }} p_{\text {st }}$ is the predicted employment rate of older people. In both equation (3) and (4), $X_{s t}$ includes a set of state-specific, time-varying explanatory variables as specified in equation (2). Since the literature suggests that the mortality rates of young adults are more

\footnotetext{
${ }^{14}$ Pro-cyclical mortality rates are documented in the literature. For instance, Ruhm (2000) reports that a 1percentage point increase in a state's unemployment rate leads to a 0.54 percent reduction in that state's mortality rate. But recent research suggests pro-cyclical relationship disappears.

${ }^{15}$ Other possible sources of concern include the quality of health care in the area and the educational or racial composition of the population. Fortunately, state controls are included in our TSLS estimation. Therefore, any statelevel time-invariant factors that may simultaneously impact both older and younger persons' health are controlled for.

${ }^{16}$ In addition, we conducted reduced-form estimation with the older persons' mortality rate as an independent variable. The results show that there is not statistically significant relationship between the their mortality rate and the labor supply of the young/prime age (Appendix Table 2).
} 
sensitive to the business cycle, the natural log of the mortality rates of young (prime-aged) individuals are also included as a control.

The results from estimating equation (3) and (4) for unemployment, employment, hours worked, and wage rates are summarized in Table 8. Even if instruments are relevant, they might be weak. In that case, instrumental variable estimates may be inconsistent and imprecisely measured. Therefore, Table 8 also reports the first stage results and the F-statistic, which tests whether the coefficient of the instrument is zero.

The first stage results show that the instrument tends to have the expected sign and is statistically significant - that is, the mortality rates of older men are negatively correlated to their employment. For instance, in the regression for younger worker's unemployment, a 1-percent increase in older men's mortality rates is predicted to decrease employment among older people by 0.09 percentage points. The first stage results also show that, with the exception of women, the instrumental variable is strong with the F-statistics over 10.

For young workers, compared to the results without correcting for endogeneity, all coefficients switch signs, though none of them is significant. The coefficients and their standard errors tend to be very large, which is typical in instrumental variables estimation. The message is clear and consistent with the earlier analysis showing no evidence of a crowd-out effect. The effect of employment of older people on the employment and wage patterns of the young is best summarized as absent.

For the prime-aged, the instrumental variable estimates are largely consistent with the OLS estimates: all four coefficients display the same signs with larger magnitude. Instead of finding a crowd-out effect, increased employment of older people positively impacts the employment of the prime-aged and leads to an increase in hours worked by this group. Turning to Panel B for men, all of the instrumental variable estimates are large, and six of the eight are insignificant. But two instances produce statistically significant coefficients. First, increased older male employment leads to a decline in hours worked by young men, but the effect is only significant at the 10 percent level. On the other hand, a 1-percentage-point increase in older male employment leads to a 0.34 point increase in employment of prime-aged men. This result strongly undermines the notion of a trade-off between the old and other age groups' employment. 
For women, Panel C provides no evidence of crowd-out. Rather, employment of older women positively impacts employment and hours worked by prime-aged women. Since the mortality rates do not provide a powerful instrument for employment by older women (the Fstatistic is less than 10), the result could mean either that no systematic effect exists or that the instruments do not allow precise estimates.

To summarize, the IV estimates provide no evidence that changes in employment rates of older Americans adversely affect the employment rate of the young.

\section{Evidence from China}

Background. Most of the research on the substitution between the old and the young focuses on developed countries. But developing countries, such as China, often make policy on the assumption that the lump-of-labor theory applies. Since the labor market in developing countries is still in transition with the rapidly changing of the nature of the jobs and the skills of workers, the relationship between the old and the young may be different. This section provides evidence on the relationship between older and younger persons' labor force outcomes in China.

China's rising longevity and falling fertility, accelerated by the one-child policy, has resulted in a dramatic demographic transformation: in 1970, about 4 percent of the population was aged 65 or older; the number jumped to 8 percent in 2010; and is expected to leap to 24 percent by $2030 .{ }^{17}$ The effect of dramatic aging in populations has been compounded by another factor: the statutory retirement age in China is very low - 50 for women ( 55 for those in managerial positions) and 60 for men (65 at the executive level in State Owned Enterprises). If these retirement ages continue, in 2050, China would have 79 retired people for 100 working age persons, which would place immense pressure of China's retirement income system (Jackson et al., 2009; Sin, 2005; Sun and Maxwell, 2002). The most obvious relief would be to raise the retirement age, but Chinese policymakers fear that such a change would hurt young workers. ${ }^{18}$

Only one study, Zhang and Zhao (2012), has examined the relationship between older persons' employment and youth employment in China. These researchers find that no evidence that the delayed retirement of older workers hurts the young. While Zhang and Zhao (2012)

\footnotetext{
${ }^{17}$ United Nations Population Division.

${ }^{18}$ The minister of the Ministry of Human Resources and Social Security has publicly announced that any reforms to the retirement system should take into account of the employment situation, especially that of young graduates. See, http://news.163.com/10/0916/03/6GM1PC5B0001124J.html.
} 
provide the first piece of evidence on potential crowding-out in China, their paper potentially suffers from endogenous concerns. ${ }^{19}$ Moreover, the authors do not explore the possibility of differential impacts by education groups.

Empirical Results. The data for this part of analysis is the population survey by China's Census Bureau for 1990, 2000, and 2005. The 1990 data are at the individual-level with a 1percent sample of population survey, and the 2000 and 2005 data are at the province-level aggregated from a sample of 10 percent of the population and 1 percent of the population , respectively. The data include detailed information about labor-force participation and an array of demographic characteristics. We divide our sample into three age groups: 20-24 (the “young”), 25-49 ("prime age;" 25-44 for women), and 50-64 (the "old;" 45-59 for women). The definition of age groups differs from those used for the U.S. analysis because of China's early statutory retirement ages. Those who work in the agricultural sector and students at school are excluded from the analysis

Consistent with our analytical strategy of using state-level variation in the United States, the Chinese analysis focuses on the country's 31 provincial-level divisions. ${ }^{20}$ The provinces show substantial variation in local labor markets and labor supply across provinces and over time in China (Table 9). Further, while the statutory retirement age is consistent across the country, workers in the private sector face fewer restrictions on when to exit from the labor market. This variation leads to substantial variation in both the share of older workers in the labor force and the unemployment rate. For example, in Jiangsu Province in 2005, nearly 63 percent of men ages 50-64 were in the labor force, compared to only 52 percent in Jiangxi. Similarly, the

\footnotetext{
${ }^{19}$ Zhang and Zhao's paper potentially suffers from endogeneity problems, because that the instrumental variable the authors employed - the share of workers whose age is approaching the retirement age in law in the public sector -- is closely correlated to the industrial structure, a factor that may simultaneously impact employment of both older and younger workers. As a result, the exclusion restriction in two-stage-least-square estimation is potentially violated. Further, in Zhang and Zhao (2012), the young age group is defined as individuals aged 20 to 24 , for either male or female. The prime age group is defined as individuals aged 25 to 54 for male, and 25 to 49 for female. The older worker group is defined as individuals aged 55 to 64 for male and 50 to 59 for female. Based on their definition, only about 29 percent to 33 percent of male older workers and 14 percent to 18 percent of female older workers participated in the labor force over time. Given the magnitude of these variables, it may not be surprising that no measurable relationship between the elderly and the young is detected.

${ }^{20}$ There are 22 provinces in China, four municipalities, five autonomous regions, two Special Administrative Regions in China. Our analysis excludes the Administrative Regions, which are Hong Kong and Macau.
} 
unemployment rate was 3.7 percent in Shandong, while neighboring Shaanxi had unemployment of 6.7 percent.

Table 10 presents the descriptive statistics. These statistics reflect 84 province-level observations for waves 1990, 2000, and 2005, with a few exceptions due to data limitations. On average, the unemployment rate of the young is 10 percent, but ranges from 4 percent to 25 percent. The within-province variation over time is large as well. The average unemployment rate of the prime-aged is lower (at 5 percent), with a smaller variance. The average employment rate for the young, the prime-aged, and the old is 64 percent, 80 percent, and 38 percent, respectively. The employment rate is higher for men than for women.

Table 11 displays the OLS regression results of equation (1). ${ }^{21}$ Consistent with our U.S. analysis, no sign of crowd out is evident, although most of coefficients are not significant. The same pattern emerges for the prime-aged as for the young: instead of finding any crowding out, the employment of older people has no effect on unemployment by the prime-age, but it significantly increases the employment of this group. The results by gender are largely consistent with the aggregate analysis (Table 12). If anything, employment of older people is positively associated with employment of the young and the prime-aged.

To address endogeneity concerns, we again employ an instrumental variable (IV) approach. While state-year-age specific mortality rates have been shown as an appropriate IV for the United States, such data are not available for the Chinese analysis. Instead, we use the share of all older persons whose age is approaching the statutory retirement age among the "old" group. The intuition is that if this share is large, the labor force participation of older people should be small. On the other hand, this variable should not be correlated with the employment/unemployment of younger people.

The TSLS results are summarized in Table 13. The first-stage results show that the instrument tends to have the expected sign and is statistically significant. For instance, in the regression for younger worker's unemployment, a 1-percent increase in the share of older workers approaching the statutory retirement age is predicted to decrease employment among

\footnotetext{
${ }^{21}$ The differences in the number of observations used in regression analysis are due to the data availability. For some provinces, the information is not available for some waves. The high $\mathrm{R}$ squares of the regressions are driven by the state-year fixed effects.
} 
older workers by 0.72 percentage points. However, all of the instrumental variables are weak, with the F-statistics less than 10, which may due to a small sample.

Our TSLS results are consistent with our OLS results - there is no evidence of a crowdout effect; the impact of employment of older people on the employment of the young and the prime-aged is best summarized as absent. The conclusion holds for both men and women. Since the share of older workers whose age is approaching the statutory retirement age does not provide a powerful instrument for employment by older persons, the result could mean either that no systematic effect exists or that the instrument does not allow precise estimates.

Robustness Check. While the analysis conducted above provides no evidence in China that changes in employment rates for older people adversely affect the employment rates of the young, the results potentially suffer from the possibility that the sample size does not allow precise estimates. To address that problem, we test the robustness of our results by using data for roughly 350 prefectures. $^{22}$ Since the prefecture-level data are available only for one year (1990), only cross sectional analysis is possible.

The results of OLS and TSLS in the prefecture-level analysis in Table 14 are consistent with those of the province-level analysis: none of the results support the crowd-out hypothesis (Panel A). If anything, employment among older people is positively associated with employment among the young and the prime-aged and is negatively associated with unemployment for these other age group. The rich information in the 1990 Census also allows us to explore whether the effects are different by education groups. Panel B of Table 14 summarizes the results for those with high-school-and-less education. The only significant estimate suggests that more low-educated older persons' employment leads to an increase in employment of low-educated young people. In short, consistent with our U.S. analysis, the relationship in China between older and younger persons' labor-force behavior does not vary by educational attainment.

\footnotetext{
${ }^{22}$ For the descriptive statistics of the prefecture-level data, please check the Appendix Table 3.
} 


\section{Conclusion}

The lump-of-labor theory can have an important impact on employment and retirement policy. In the United States, in the context of delayed retirement by older workers during the Great Recession, heightened media attention focused on the potential employment crowd out between younger and older workers. In China, acceptance of the lump-of-labor theory helps explain the very early statutory retirement ages.

For the United States, this paper uses interstate and within-state variation to investigate whether increasing the employment of older people reduces the job opportunities or wage rates of young people. The results show no evidence of crowd out of the young by older workers that would support the lump-of-labor theory. The patterns are consistent for both men and women and for groups with different levels of education. Because the positive results could reflect general labor market conditions that impact both the young and the old, an instrumental variables model is employed. The instrumental variable approach does not produce any consistent evidence that changes in the employment rates of older workers adversely affect the employment and wage rate of their younger counterparts. If anything, the opposite is true. Moreover, the effects of older persons' employment on other segments of the labor market during the Great Recession do not differ from those during typical business cycles. The analysis of Chinese data produces similar results: the employment of older workers has no impact on labor market perspectives of other age groups.

Convincing employers and policymakers that the lump-of-labor theory does not hold is extremely important, given the state of the U.S. retirement system and the need for people to work longer in order to have a secure retirement and given the growing burden of retirees in China. Employers already have reservations about older workers, so adding the false argument that retaining older workers hurts younger ones could impede the ability of older workers to remain in the labor force. Therefore, public discourse will be improved by putting the lump-oflabor theory to rest. 


\section{References:}

Brandon, Emily. 2009. "Delayed Retirement May Mean Fewer Job Openings." U.S. News \& World Report, September 3. Available at:

http://money.usnews.com/money/blogs/planning-to-retire/2009/09/03/delayedretirement-may-mean-fewer-job-openings.html.

Black, Dan, Natalia Kolesnikova, and Lowell J. Taylor. 2007. "Why Do So Few Women Work in New York (and So Many in Minneapolis?) Labor Supply of Married Women Across U.S. Cities." Federal Reserve Bank of St. Louis Working Paper.

Blanchard, Oliver J. and Stanley Fischer. 1989. Lectures on Macroeconomics. Cambridge, MA: MIT Press.

Borjas, George J. 2006. "Native Internal Migration and the Labor Market Impact of Immigration.” Journal of Human Resources, 41(2): 221-258.

Card, David. 2001. "Immigrant Inflows, Native Outflows, and the Local Labor Market Impacts of Higher Immigration.” Journal of Labor Economics, 19(1): 22-64.

Card, David. 2005. "Is the New Immigration Really So Bad?" The Economic Journal, 115(507): F300-F323.

Compton, Janice and Robert Pollak. 2011. "Family Proximity, Childcare, and Women's Labor Force Attachment.” National Bureau of Economic Research Working Paper 17678.

Cinko, Andrew, Michael McDonough, and Courtney Schlisserman. 2010. "Workers of 65 Vie with Teens in Labor Market for First Time Since Truman." Bloomberg, July 13. Available at: http://www.bloomberg.com/insight/teens.html.

Dickler, Jessica. 2010. "Battle Brews Over Hourly Jobs." CNN Money, February 2. Available at: http://money.cnn.com/2010/02/02/news/economy/hourly_jobs/.

Fetter, Frank A. 1913. "Population or Prosperity: Annual Address of the President." The American Economic Review 3(1): 5-19.

Friedberg, Leora and Anthony Webb. 2005. "Retirement and the Evolution of Pension Structure." Journal of Human Resources 40(2): 281-308. 
Gandel, Stephen. 2010. "In a Tough Job Market, Teens Are Suffering Most.” Time, January 18. Available at: http://www.time.com/time/magazine/article/0,9171,1952331-1,00.html.

Greenhouse, Steven. 2009. "Young and Old Are Facing Off for Jobs." New York Times, March 20. Available at: http://www.nytimes.com/2009/03/21/business/21age.html?_r=1.

Greenwood, Michael J. and John M. McDowell. 1986. "The Factor Market Consequences of U.S. Immigration.” Journal of Economic Literature 24(4): 1738-1772.

Gruber, Jonathan and David A. Wise, eds. 2010. Social Security Programs and Retirement around the World: The Relationship to Youth Employment. Chicago, IL and London: The University of Chicago Press.

Gruber, Jonathan and Kevin Milligan. 2008. "Do Elderly Workers Substitute for Younger Workers in the United States?" In Social Security Programs and Retirement around the World: The Relationship to Youth Employment, edited by Jonathan Gruber and David A. Wise, 345-360. Chicago, IL and London: The University of Chicago Press.

Gruber, Jonathan and Jeffrey D. Kubik. 1997. "Disability Insurance Rejection Rates and the Labor Supply of Older Workers.” Journal of Public Economics 64(1): 1-23.

Haider, Steven J. and Melvin Stephens Jr. 2007. "Is There a Retirement-Consumption Puzzle? Evidence Using Subjective Retirement Expectations." The Review of Economics and Statistics, 89(2): 247-264.

Hamilton, Barton H. 2000. "Does Entrepreneurship Pay? An Empirical Analysis of the Returns to Self-Employment." Journal of Political Economy, 108(3): 604-631.

Hurd, Michael and Suann Rohwedder. 2008. "The Retirement Consumption Puzzle: Actual Spending Change in Panel Data." National Bureau of Economic Research Working Paper 13929.

Hurd, Michael and Susann Rohwedder. 2003. "The Retirement Consumption Puzzle: Anticipated and Actual Declines in Retirement Spending." National Bureau of Economic Research Working Paper 9586.

Jackson, Richard, Keisuke Nakashima, and Neil Howe. 2009. "China's Long March to Retirement Reform: the Graying of the Middle Kingdom Revisited," Center for Strategic and International Studies, Washington, DC. 
LaLonde, Robert J. and Robert H. Topel. 1991. "Labor Market Adjustments to Increased Immigration.” In Immigration, Trade, and the Labor Market: 167-200. Chicago: University of Chicago Press.

Lucas Jr., Robert J. 1977. “Understanding Business Cycles.” Carnegie-Rochester Conference Series on Public Policy, 5: 7-29.

Mankiw, N. Gregory. 1989. “Real Business Cycles: A New Keynesian Perspective,” The Journal of Economic Perspectives 3(3): 79-90.

Mayhew, Henry. 1864. "Skilled and Unskilled Labour." In London Labour and the London Poor: The Condition and Earnings of Those that Will Work, Cannot Work, and Will Not Work, 3: 231-241. London: Charles Griffen and Company.

McGarry, Kathleen. 2004. "Health and Retirement: Do Changes in Health Affect Retirement Expectations?” Journal of Human Resources, 39(4): 624-648.

Munnell, Alicia H. and Steven A. Sass. 2008. Working Longer: The Solution to the Retirement Income Challenge. Washington, DC: Brookings Institution Press.

Munnell, Alicia H., Mauricio Soto, Robert K. Triest, and Natalia A. Zhivan. 2008. "How Much Do State Economics and Other Characteristics Affect Labor Force Participation of Older Workers?" Working Paper 2008-12. Chestnut Hill, MA: Center for Retirement Research at Boston College.

Mutikani, Lucia. 2010. “Older, Young U.S. Workers Jostle for Scarce Jobs.” Reuters, April 7. Available at: http://www.reuters.com/article/idUSTRE63646920100407.

Odland, John and Mark Ellis. 1998. "Variations in Labour Force Experience of Women Across Large Metropolitan Areas in the United States." Regional Studies 32(4): 333-347.

Peri, Giovanni and Chad Sparber. 2009. "Task Specialization, Immigration, and Wages." American Economic Journal: Applied Economics, 1(3): 135-169.

Ruhm, Christopher J. 2000. “Are Recessions Good For Your Health?” The Quarterly Journal of Economics, 115(2): 617-650.

Samuelson, Paul and William Nordhaus. 2004. Economics. New York: McGraw-Hill. 
Schloss, David F. 1891. "Why Working-Men Dislike Piece-Work.” Economic Review, 1(3): 311326.

Sin, Yvonne. 2005. "China: Pension Liabilities and Reform Options for Old-age Insurance," World Bank Working Paper Series, No. 2005-1.

Smith, Sarah. 2006. "The Retirement-Consumption Puzzle and Involuntary Early Retirement: Evidence from the British Household Survey.” The Economic Journal, 116(510): C130C148.

Solon, Gary, Robert Barsky, and Johnathan A. Parker. 1994. "Measuring the Cyclicality of Real Wages: How Important is Composition Bias?" The Quarterly Journal of Economics, 109(1): $1-25$.

Stevens, Ann Huff, Douglas L. Miller, Marianne E. Page, and Mateusz Filipski. 2011. "The Best of Times, The Worst of Times: Understanding Pro-Cyclical Mortality.” National Bureau of Economic Research Working Paper 17657.

Sun, Qixiang and John W. Maxwell. 2002. "Deficits, Empty Individual Accounts, and Transition Costs: Restructuring Challenges Facing China's Pension System," Journal of Insurance Issues, 25, 2, pp. 103-126.

U.S. Bureau of Labor Statistics. Current Population Survey, 1990-2010. Washington, DC.

Valetkevitch, Caroline. 2010. "Older Workers Sticking with Jobs; Employment for Youngest Falls.” Insurance Journal, April 9. Available at: http://www.insurancejournal.com/news/national/2010/04/09/108893.htm.

Van Dalen, Hendrik P. and Kene Henkens. 2002. "Early Retirement Reform: Can it and Will it Work?” Ageing \& Society 22: 209-231.

Ward, Clare and Angela Dale. 1992. "Geographical Variation in Female Labour Force Participation: An Application of Multilevel Modelling" Regional Studies, 26(3); 243255.

Zhang, Chuanchuan and Yaohui Zhao. 2012. "The relationship between elderly employment and youth employment: evidence from China.” Working paper, MPRA Paper No. 37221 
Table 1.1. U.S. Labor Force Participation Rates of Older Persons, by State

\begin{tabular}{|c|c|c|c|c|c|}
\hline \multirow{2}{*}{ State } & \multicolumn{5}{|c|}{ CPS Year } \\
\hline & 2011 & 2000 & 1990 & 1980 & 1977 \\
\hline AK & 0.59 & 0.71 & 0.54 & 0.64 & 0.61 \\
\hline AL & 0.55 & 0.54 & 0.40 & 0.51 & 0.45 \\
\hline AR & 0.54 & 0.48 & 0.50 & 0.50 & 0.51 \\
\hline AZ & 0.58 & 0.49 & 0.41 & 0.44 & 0.45 \\
\hline $\mathrm{CA}$ & 0.59 & 0.59 & 0.55 & 0.50 & 0.52 \\
\hline $\mathrm{CO}$ & 0.63 & 0.70 & 0.56 & 0.57 & 0.55 \\
\hline CT & 0.72 & 0.65 & 0.64 & 0.68 & 0.57 \\
\hline DC & 0.62 & 0.69 & 0.57 & 0.52 & 0.55 \\
\hline $\mathrm{DE}$ & 0.63 & 0.62 & 0.49 & 0.60 & 0.54 \\
\hline FL & 0.61 & 0.56 & 0.51 & 0.48 & 0.45 \\
\hline GA & 0.56 & 0.56 & 0.49 & 0.56 & 0.52 \\
\hline $\mathrm{HI}$ & 0.68 & 0.71 & 0.61 & 0.59 & 0.63 \\
\hline IA & 0.73 & 0.64 & 0.61 & 0.61 & 0.62 \\
\hline ID & 0.59 & 0.67 & 0.51 & 0.49 & 0.55 \\
\hline IL & 0.63 & 0.62 & 0.56 & 0.62 & 0.61 \\
\hline IN & 0.58 & 0.60 & 0.51 & 0.61 & 0.52 \\
\hline KS & 0.62 & 0.72 & 0.68 & 0.69 & 0.65 \\
\hline KY & 0.56 & 0.52 & 0.53 & 0.47 & 0.48 \\
\hline LA & 0.44 & 0.49 & 0.46 & 0.49 & 0.50 \\
\hline MA & 0.62 & 0.68 & 0.57 & 0.61 & 0.61 \\
\hline MD & 0.59 & 0.61 & 0.55 & 0.55 & 0.55 \\
\hline ME & 0.58 & 0.64 & 0.56 & 0.53 & 0.55 \\
\hline MI & 0.50 & 0.53 & 0.45 & 0.51 & 0.52 \\
\hline MN & 0.64 & 0.66 & 0.67 & 0.60 & 0.55 \\
\hline MO & 0.57 & 0.60 & 0.61 & 0.53 & 0.54 \\
\hline MS & 0.50 & 0.52 & 0.49 & 0.52 & 0.53 \\
\hline MT & 0.63 & 0.62 & 0.53 & 0.55 & 0.54 \\
\hline $\mathrm{NC}$ & 0.57 & 0.55 & 0.53 & 0.51 & 0.53 \\
\hline ND & 0.80 & 0.68 & 0.67 & 0.57 & 0.60 \\
\hline NE & 0.70 & 0.72 & 0.60 & 0.61 & 0.57 \\
\hline $\mathrm{NH}$ & 0.72 & 0.70 & 0.63 & 0.62 & 0.61 \\
\hline NJ & 0.68 & 0.64 & 0.62 & 0.58 & 0.52 \\
\hline NM & 0.53 & 0.55 & 0.45 & 0.51 & 0.51 \\
\hline NV & 0.58 & 0.52 & 0.58 & 0.56 & 0.59 \\
\hline NY & 0.61 & 0.55 & 0.54 & 0.54 & 0.55 \\
\hline $\mathrm{OH}$ & 0.62 & 0.58 & 0.51 & 0.56 & 0.56 \\
\hline OK & 0.61 & 0.53 & 0.58 & 0.55 & 0.57 \\
\hline OR & 0.63 & 0.54 & 0.47 & 0.53 & 0.53 \\
\hline PA & 0.61 & 0.61 & 0.51 & 0.51 & 0.52 \\
\hline RI & 0.61 & 0.59 & 0.50 & 0.57 & 0.53 \\
\hline $\mathrm{SC}$ & 0.49 & 0.46 & 0.53 & 0.39 & 0.50 \\
\hline SD & 0.66 & 0.69 & 0.58 & 0.68 & 0.66 \\
\hline $\mathrm{TN}$ & 0.57 & 0.55 & 0.51 & 0.43 & 0.49 \\
\hline TX & 0.60 & 0.57 & 0.53 & 0.52 & 0.56 \\
\hline UT & 0.66 & 0.56 & 0.52 & 0.64 & 0.55 \\
\hline VA & 0.63 & 0.56 & 0.53 & 0.54 & 0.59 \\
\hline VT & 0.75 & 0.68 & 0.62 & 0.52 & 0.48 \\
\hline WA & 0.61 & 0.57 & 0.51 & 0.49 & 0.50 \\
\hline WI & 0.66 & 0.58 & 0.60 & 0.61 & 0.62 \\
\hline WV & 0.49 & 0.42 & 0.38 & 0.39 & 0.41 \\
\hline WY & 0.69 & 0.61 & 0.52 & 0.60 & 0.58 \\
\hline 10th percentile & 0.53 & 0.52 & 0.46 & 0.48 & 0.48 \\
\hline 25 th percentile & 0.57 & 0.55 & 0.51 & 0.51 & 0.52 \\
\hline 50th percentile & 0.61 & 0.59 & 0.53 & 0.55 & 0.55 \\
\hline 75th percentile & 0.64 & 0.66 & 0.58 & 0.60 & 0.58 \\
\hline 90th percentile & 0.70 & 0.70 & 0.62 & 0.62 & 0.61 \\
\hline
\end{tabular}


Table 1.2. U.S. Labor Force Participation Rates of the Young, by State

\begin{tabular}{|c|c|c|c|c|c|}
\hline \multirow{2}{*}{ State } & \multicolumn{5}{|c|}{ CPS Year } \\
\hline & 2011 & 2000 & 1990 & 1980 & 1977 \\
\hline AK & 0.64 & 0.60 & 0.59 & 0.55 & 0.52 \\
\hline $\mathrm{AL}$ & 0.61 & 0.69 & 0.65 & 0.61 & 0.58 \\
\hline $\mathrm{AR}$ & 0.69 & 0.62 & 0.66 & 0.67 & 0.61 \\
\hline $\mathrm{AZ}$ & 0.53 & 0.70 & 0.64 & 0.68 & 0.58 \\
\hline $\mathrm{CA}$ & 0.56 & 0.68 & 0.68 & 0.70 & 0.61 \\
\hline $\mathrm{CO}$ & 0.61 & 0.77 & 0.72 & 0.73 & 0.65 \\
\hline CT & 0.59 & 0.70 & 0.73 & 0.70 & 0.62 \\
\hline DC & 0.50 & 0.62 & 0.70 & 0.59 & 0.51 \\
\hline $\mathrm{DE}$ & 0.54 & 0.79 & 0.75 & 0.65 & 0.59 \\
\hline FL & 0.56 & 0.71 & 0.70 & 0.70 & 0.67 \\
\hline GA & 0.58 & 0.78 & 0.68 & 0.69 & 0.63 \\
\hline HI & 0.63 & 0.68 & 0.69 & 0.59 & 0.72 \\
\hline IA & 0.69 & 0.72 & 0.76 & 0.76 & 0.73 \\
\hline ID & 0.58 & 0.74 & 0.72 & 0.61 & 0.62 \\
\hline IL & 0.58 & 0.72 & 0.70 & 0.64 & 0.63 \\
\hline IN & 0.61 & 0.63 & 0.70 & 0.65 & 0.67 \\
\hline KS & 0.61 & 0.75 & 0.79 & 0.74 & 0.78 \\
\hline KY & 0.64 & 0.73 & 0.73 & 0.63 & 0.70 \\
\hline LA & 0.52 & 0.53 & 0.56 & 0.64 & 0.62 \\
\hline MA & 0.60 & 0.62 & 0.74 & 0.69 & 0.66 \\
\hline MD & 0.67 & 0.67 & 0.77 & 0.69 & 0.67 \\
\hline $\mathrm{ME}$ & 0.59 & 0.71 & 0.71 & 0.60 & 0.61 \\
\hline MI & 0.60 & 0.79 & 0.66 & 0.60 & 0.64 \\
\hline $\mathrm{MN}$ & 0.73 & 0.81 & 0.79 & 0.76 & 0.72 \\
\hline MO & 0.66 & 0.74 & 0.69 & 0.72 & 0.71 \\
\hline MS & 0.57 & 0.62 & 0.66 & 0.70 & 0.59 \\
\hline MT & 0.57 & 0.73 & 0.75 & 0.65 & 0.63 \\
\hline $\mathrm{NC}$ & 0.58 & 0.71 & 0.73 & 0.68 & 0.67 \\
\hline ND & 0.68 & 0.77 & 0.75 & 0.66 & 0.64 \\
\hline $\mathrm{NE}$ & 0.76 & 0.82 & 0.80 & 0.71 & 0.78 \\
\hline $\mathrm{NH}$ & 0.67 & 0.80 & 0.81 & 0.82 & 0.74 \\
\hline NJ & 0.60 & 0.69 & 0.68 & 0.65 & 0.60 \\
\hline NM & 0.55 & 0.63 & 0.68 & 0.62 & 0.56 \\
\hline NV & 0.69 & 0.80 & 0.73 & 0.74 & 0.65 \\
\hline NY & 0.51 & 0.61 & 0.62 & 0.62 & 0.59 \\
\hline $\mathrm{OH}$ & 0.64 & 0.73 & 0.66 & 0.65 & 0.67 \\
\hline OK & 0.72 & 0.68 & 0.54 & 0.65 & 0.64 \\
\hline OR & 0.62 & 0.78 & 0.69 & 0.61 & 0.64 \\
\hline PA & 0.62 & 0.66 & 0.73 & 0.69 & 0.63 \\
\hline RI & 0.62 & 0.82 & 0.65 & 0.76 & 0.72 \\
\hline SC & 0.48 & 0.67 & 0.72 & 0.59 & 0.60 \\
\hline SD & 0.69 & 0.82 & 0.63 & 0.70 & 0.72 \\
\hline $\mathrm{TN}$ & 0.57 & 0.80 & 0.61 & 0.69 & 0.61 \\
\hline TX & 0.59 & 0.66 & 0.70 & 0.66 & 0.66 \\
\hline UT & 0.67 & 0.80 & 0.76 & 0.66 & 0.69 \\
\hline VA & 0.61 & 0.72 & 0.73 & 0.66 & 0.69 \\
\hline VT & 0.73 & 0.70 & 0.72 & 0.67 & 0.58 \\
\hline WA & 0.61 & 0.76 & 0.73 & 0.60 & 0.60 \\
\hline WI & 0.64 & 0.79 & 0.77 & 0.71 & 0.69 \\
\hline WV & 0.52 & 0.64 & 0.54 & 0.55 & 0.52 \\
\hline WY & 0.62 & 0.67 & 0.59 & 0.72 & 0.65 \\
\hline 10th percentile & 0.53 & 0.62 & 0.61 & 0.60 & 0.58 \\
\hline 25th percentile & 0.57 & 0.67 & 0.66 & 0.62 & 0.60 \\
\hline 50th percentile & 0.61 & 0.71 & 0.70 & 0.66 & 0.64 \\
\hline 75th percentile & 0.66 & 0.78 & 0.73 & 0.70 & 0.69 \\
\hline 90th percentile & 0.69 & 0.80 & 0.77 & 0.74 & 0.72 \\
\hline
\end{tabular}


Table 1.3. U.S. Labor Force Participation Rates of the Prime-Aged, by State

\begin{tabular}{|c|c|c|c|c|c|}
\hline \multirow{2}{*}{ State } & \multicolumn{5}{|c|}{ CPS Year } \\
\hline & 2011 & 2000 & 1990 & 1980 & 1977 \\
\hline $\mathrm{AK}$ & 0.73 & 0.74 & 0.73 & 0.66 & 0.66 \\
\hline $\mathrm{AL}$ & 0.68 & 0.80 & 0.78 & 0.72 & 0.69 \\
\hline AR & 0.71 & 0.81 & 0.77 & 0.72 & 0.68 \\
\hline $\mathrm{AZ}$ & 0.71 & 0.78 & 0.80 & 0.74 & 0.70 \\
\hline $\mathrm{CA}$ & 0.70 & 0.77 & 0.77 & 0.75 & 0.71 \\
\hline $\mathrm{CO}$ & 0.77 & 0.82 & 0.81 & 0.81 & 0.73 \\
\hline CT & 0.78 & 0.86 & 0.85 & 0.80 & 0.74 \\
\hline DC & 0.77 & 0.83 & 0.80 & 0.80 & 0.74 \\
\hline $\mathrm{DE}$ & 0.77 & 0.83 & 0.81 & 0.71 & 0.73 \\
\hline FL & 0.73 & 0.81 & 0.80 & 0.74 & 0.70 \\
\hline GA & 0.70 & 0.82 & 0.80 & 0.75 & 0.75 \\
\hline $\mathrm{HI}$ & 0.76 & 0.81 & 0.74 & 0.75 & 0.77 \\
\hline IA & 0.81 & 0.90 & 0.86 & 0.78 & 0.74 \\
\hline ID & 0.73 & 0.82 & 0.81 & 0.76 & 0.69 \\
\hline IL & 0.74 & 0.83 & 0.79 & 0.74 & 0.72 \\
\hline IN & 0.73 & 0.81 & 0.79 & 0.74 & 0.72 \\
\hline KS & 0.79 & 0.83 & 0.81 & 0.80 & 0.74 \\
\hline KY & 0.71 & 0.79 & 0.76 & 0.74 & 0.72 \\
\hline LA & 0.67 & 0.74 & 0.69 & 0.71 & 0.65 \\
\hline MA & 0.79 & 0.84 & 0.81 & 0.76 & 0.71 \\
\hline MD & 0.80 & 0.88 & 0.85 & 0.77 & 0.73 \\
\hline ME & 0.75 & 0.83 & 0.78 & 0.72 & 0.69 \\
\hline MI & 0.71 & 0.82 & 0.75 & 0.70 & 0.69 \\
\hline MN & 0.83 & 0.88 & 0.84 & 0.79 & 0.74 \\
\hline MO & 0.76 & 0.85 & 0.80 & 0.76 & 0.72 \\
\hline MS & 0.70 & 0.78 & 0.75 & 0.74 & 0.72 \\
\hline MT & 0.79 & 0.83 & 0.82 & 0.76 & 0.73 \\
\hline $\mathrm{NC}$ & 0.73 & 0.83 & 0.83 & 0.76 & 0.73 \\
\hline ND & 0.86 & 0.87 & 0.80 & 0.77 & 0.69 \\
\hline NE & 0.84 & 0.87 & 0.84 & 0.79 & 0.77 \\
\hline NH & 0.82 & 0.85 & 0.83 & 0.78 & 0.75 \\
\hline NJ & 0.74 & 0.81 & 0.81 & 0.74 & 0.69 \\
\hline NM & 0.69 & 0.80 & 0.75 & 0.69 & 0.66 \\
\hline NV & 0.73 & 0.81 & 0.80 & 0.79 & 0.74 \\
\hline NY & 0.73 & 0.78 & 0.76 & 0.71 & 0.65 \\
\hline $\mathrm{OH}$ & 0.74 & 0.80 & 0.80 & 0.71 & 0.70 \\
\hline OK & 0.73 & 0.79 & 0.79 & 0.74 & 0.77 \\
\hline OR & 0.76 & 0.85 & 0.79 & 0.73 & 0.66 \\
\hline PA & 0.76 & 0.82 & 0.78 & 0.71 & 0.66 \\
\hline RI & 0.74 & 0.81 & 0.79 & 0.76 & 0.69 \\
\hline $\mathrm{SC}$ & 0.73 & 0.84 & 0.81 & 0.71 & 0.71 \\
\hline SD & 0.84 & 0.91 & 0.84 & 0.78 & 0.71 \\
\hline $\mathrm{TN}$ & 0.74 & 0.81 & 0.76 & 0.73 & 0.70 \\
\hline TX & 0.74 & 0.80 & 0.77 & 0.74 & 0.72 \\
\hline UT & 0.75 & 0.81 & 0.79 & 0.74 & 0.71 \\
\hline VA & 0.77 & 0.85 & 0.81 & 0.74 & 0.73 \\
\hline VT & 0.81 & 0.86 & 0.86 & 0.78 & 0.69 \\
\hline WA & 0.75 & 0.79 & 0.81 & 0.75 & 0.66 \\
\hline WI & 0.83 & 0.84 & 0.84 & 0.79 & 0.74 \\
\hline WV & 0.66 & 0.76 & 0.70 & 0.63 & 0.63 \\
\hline WY & 0.80 & 0.82 & 0.83 & 0.79 & 0.76 \\
\hline 10th percentile & 0.70 & 0.78 & 0.75 & 0.71 & 0.66 \\
\hline 25th percentile & 0.73 & 0.80 & 0.77 & 0.72 & 0.69 \\
\hline 50th percentile & 0.74 & 0.82 & 0.80 & 0.74 & 0.71 \\
\hline 75th percentile & 0.79 & 0.84 & 0.81 & 0.78 & 0.74 \\
\hline 90th percentile & 0.82 & 0.87 & 0.84 & 0.79 & 0.75 \\
\hline
\end{tabular}




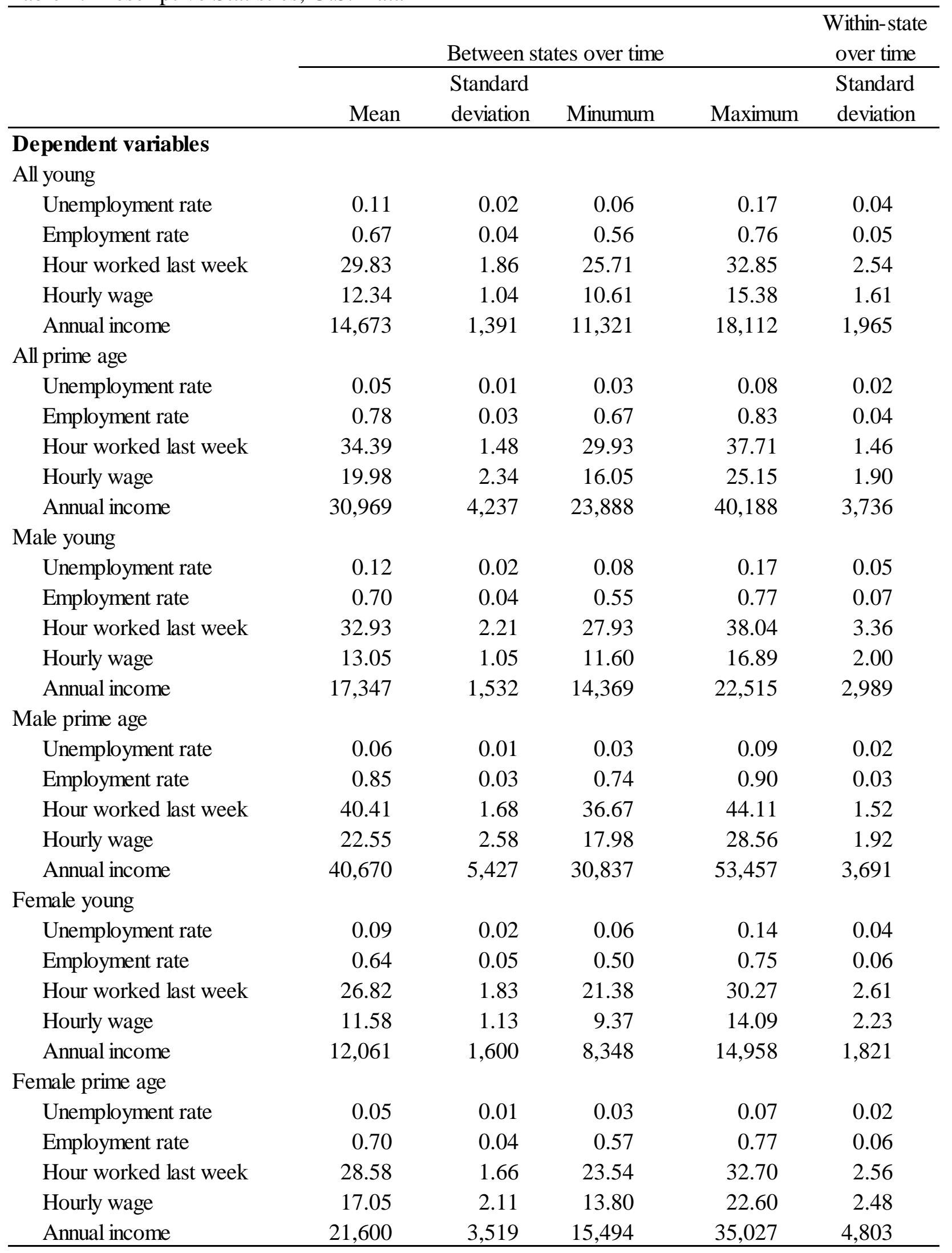


Table 2. Descriptive Statistics, U.S. Data (cont'd)

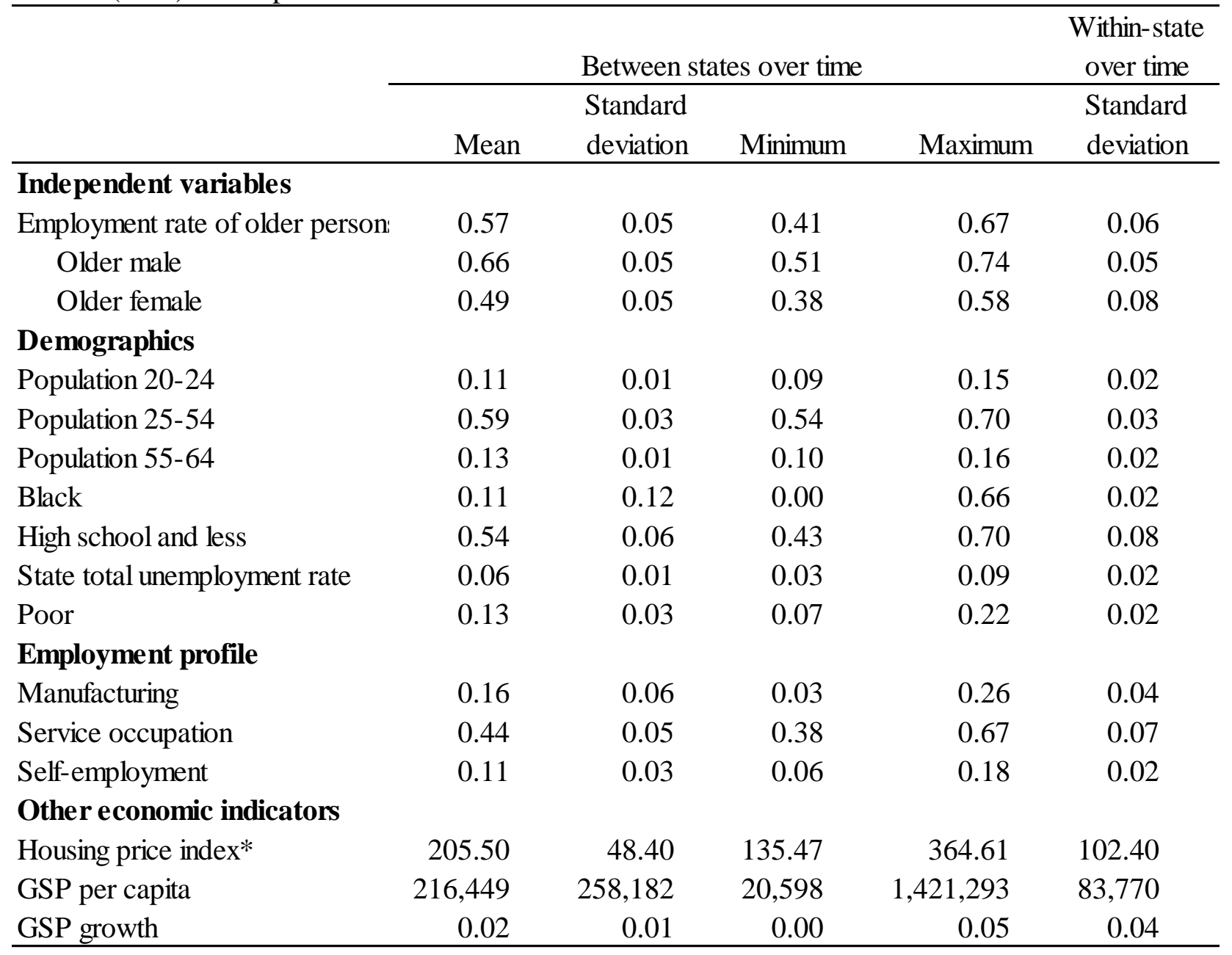

* Base year 1977. 
Table 3.1. Relationship between Older Persons' Employment and Youth Labor Market Activity (Both Sexes)

\begin{tabular}{|c|c|c|c|c|c|c|}
\hline & \multirow{2}{*}{\multicolumn{2}{|c|}{ Unemployment }} & \multicolumn{2}{|c|}{ Employment } & \multicolumn{2}{|c|}{ Hours worked $(\log )$} \\
\hline & & & $(2)$ & & (3) & \\
\hline Older persons' employment rate & -0.021 & & 0.065 & ** & 0.052 & \\
\hline & $(0.024)$ & & $(0.032)$ & & $(0.037)$ & \\
\hline Local average wage of young & -0.016 & * & 0.009 & & -0.008 & \\
\hline & (0.009) & & $(0.011)$ & & $(0.016)$ & \\
\hline Fraction of black in state & 0.092 & & -0.166 & & -0.046 & \\
\hline & $(0.073)$ & & $(0.102)$ & & $(0.106)$ & \\
\hline Fraction of less than high school in state & -0.026 & & 0.028 & & -0.065 & \\
\hline & $(0.048)$ & & $(0.064)$ & & $(0.099)$ & \\
\hline State average unemployment rate & - & & - & & $\begin{array}{r}-0.887 \\
(0.160)\end{array}$ & $* * *$ \\
\hline Fraction of poor in state & $\begin{array}{r}0.297 \\
(0.062)\end{array}$ & **** & $\begin{array}{r}-0.360 \\
(0.106)\end{array}$ & $* * *$ & $\begin{array}{r}-0.340 \\
(0.152)\end{array}$ & ** \\
\hline Percent of population 20-24 & $\begin{array}{r}-0.040 \\
(0.096)\end{array}$ & & $\begin{array}{r}0.174 \\
(0.137)\end{array}$ & & $\begin{array}{r}0.396 \\
(0.152)\end{array}$ & ** \\
\hline Percent of jobs in manufacturing & $\begin{array}{r}-0.054 \\
(0.063)\end{array}$ & & $\begin{array}{r}0.257 \\
(0.079)\end{array}$ & $* * *$ & $\begin{array}{r}0.157 \\
(0.092)\end{array}$ & $*$ \\
\hline Percent of jobs in service industry & $\begin{array}{r}0.021 \\
(0.057)\end{array}$ & & $\begin{array}{r}0.021 \\
(0.081)\end{array}$ & & $\begin{array}{r}-0.385 \\
(0.110)\end{array}$ & $* * *$ \\
\hline Percent of jobs in self-employment & $\begin{array}{r}-0.117 \\
(0.063)\end{array}$ & * & $\begin{array}{r}-0.205 \\
(0.096)\end{array}$ & $* *$ & $\begin{array}{r}-0.264 \\
(0.154)\end{array}$ & $*$ \\
\hline Housing price index growth & $\begin{array}{r}-0.150 \\
(0.023)\end{array}$ & $* * *$ & $\begin{array}{r}0.181 \\
(0.030)\end{array}$ & $* * *$ & $\begin{array}{r}0.090 \\
(0.035)\end{array}$ & $* *$ \\
\hline GSP per capita $(\log )$ & $\begin{array}{r}0.005 \\
(0.010)\end{array}$ & & $\begin{array}{r}0.011 \\
(0.018)\end{array}$ & & $\begin{array}{r}0.019 \\
(0.033)\end{array}$ & \\
\hline GSP growth (percent) & $\begin{array}{r}-0.054 \\
(0.046)\end{array}$ & & $\begin{array}{c}-0.031 \\
(0.046)\end{array}$ & & $\begin{array}{r}-0.065 \\
(0.046)\end{array}$ & \\
\hline Great Recession indicator & $\begin{array}{r}0.047 \\
(0.008)\end{array}$ & $* * *$ & $\begin{array}{r}-0.050 \\
(0.009)\end{array}$ & $* * *$ & $\begin{array}{r}-0.101 \\
(0.014)\end{array}$ & $* * *$ \\
\hline Year dummies & Yes & & Yes & & Yes & \\
\hline State dummies & Yes & & Yes & & Yes & \\
\hline R squared & 0.507 & & 0.608 & & 0.731 & \\
\hline Number of observations & 1683 & & 1683 & & 1683 & \\
\hline
\end{tabular}

Note: * significant at $10 \%, * *$ significant at $5 \%, * * *$ significant at $1 \%$. 
Table 3.1. Relationship between Older Persons' Employment and Prime-aged Labor Market Activity (Both Sexes) (cont'd)

\begin{tabular}{|c|c|c|c|c|c|c|}
\hline & \multicolumn{2}{|c|}{ Unemployment } & \multicolumn{2}{|c|}{ Employment } & \multicolumn{2}{|c|}{ Hours worked $(\log )$} \\
\hline & $(1)$ & & (2) & & (3) & \\
\hline Older persons' employment rate & -0.012 & & 0.044 & **** & 0.022 & \\
\hline & $(0.009)$ & & $(0.015)$ & & $(0.019)$ & \\
\hline Local average wage of prime-aged & 0.014 & * & -0.041 & ** & -0.013 & \\
\hline & $(0.008)$ & & $(0.017)$ & & $(0.014)$ & \\
\hline Fraction of black in state & -0.008 & & 0.038 & & 0.060 & \\
\hline & $(0.022)$ & & $(0.051)$ & & $(0.054)$ & \\
\hline Fraction of less than high school in state & 0.032 & ** & -0.116 & **** & -0.181 & **** \\
\hline State average unemployment rate & $\begin{array}{c}(0.016) \\
-\end{array}$ & & $\begin{array}{c}(0.034) \\
-\end{array}$ & & $\begin{array}{r}(0.049) \\
-0.576 \\
(0.068)\end{array}$ & **** \\
\hline Fraction of poor in state & $\begin{array}{r}0.185 \\
(0.032)\end{array}$ & **** & $\begin{array}{c}-0.311 \\
(0.052)\end{array}$ & **** & $\begin{array}{r}-0.234 \\
(0.059)\end{array}$ & **** \\
\hline Percent of population 25-54 & $\begin{array}{r}0.018 \\
(0.022)\end{array}$ & & $\begin{array}{r}-0.035 \\
(0.036)\end{array}$ & & $\begin{array}{r}-0.021 \\
(0.055)\end{array}$ & \\
\hline Percent of jobs in manufacturing & $\begin{array}{r}-0.070 \\
(0.020)\end{array}$ & **** & $\begin{array}{r}0.127 \\
(0.048)\end{array}$ & **** & $\begin{array}{r}-0.078 \\
(0.055)\end{array}$ & \\
\hline Percent of jobs in service industry & $\begin{array}{r}-0.024 \\
(0.026)\end{array}$ & & $\begin{array}{r}0.055 \\
(0.042)\end{array}$ & & $\begin{array}{c}-0.131 \\
(0.044)\end{array}$ & **** \\
\hline Percent of jobs in self-employment & $\begin{array}{r}-0.046 \\
(0.022)\end{array}$ & ** & $\begin{array}{r}-0.050 \\
(0.053)\end{array}$ & & $\begin{array}{r}0.001 \\
(0.063)\end{array}$ & \\
\hline Housing price index growth & $\begin{array}{r}-0.074 \\
(0.009)\end{array}$ & **** & $\begin{array}{r}0.047 \\
(0.014)\end{array}$ & **** & $\begin{array}{r}-0.007 \\
(0.020)\end{array}$ & \\
\hline GSP per capita $(\log )$ & $\begin{array}{r}-0.004 \\
(0.005)\end{array}$ & & $\begin{array}{r}-0.001 \\
(0.011)\end{array}$ & & $\begin{array}{r}-0.013 \\
(0.013)\end{array}$ & \\
\hline GSP growth (percent) & $\begin{array}{c}-0.031 \\
(0.027)\end{array}$ & & $\begin{array}{r}0.019 \\
(0.033)\end{array}$ & & $\begin{array}{r}-0.012 \\
(0.019)\end{array}$ & \\
\hline Great Recession indicator & $\begin{array}{r}0.032 \\
(0.003)\end{array}$ & **** & $\begin{array}{r}-0.041 \\
(0.004)\end{array}$ & **** & $\begin{array}{r}-0.035 \\
(0.006)\end{array}$ & **** \\
\hline Year dummies & Yes & & Yes & & Yes & \\
\hline State dummies & Yes & & Yes & & Yes & \\
\hline R squared & 0.740 & & 0.854 & & 0.8664 & \\
\hline Number of observations & 1683 & & 1683 & & 1683 & \\
\hline
\end{tabular}

Note: $*$ significant at $10 \%, * *$ significant at $5 \%, * * *$ significant at $1 \%$. 
Table 3.2. Relationship between Older Persons' Employment and Youth and Prime-aged Labor Market Activity (by Gender)

\begin{tabular}{|c|c|c|c|c|c|}
\hline \multirow[b]{2}{*}{ Youth male } & \multirow{3}{*}{$\begin{array}{c}\text { Unemployment } \\
-0.018 \\
(0.028)\end{array}$} & \multicolumn{2}{|c|}{ Employment } & \multicolumn{2}{|c|}{$\begin{array}{c}\text { Hours worked } \\
(\log )\end{array}$} \\
\hline & & 0.061 & & 0.124 & $* * *$ \\
\hline & & $(0.037)$ & & $(0.045)$ & \\
\hline \multirow[t]{2}{*}{ Prime-aged male } & -0.012 & 0.027 & $* * *$ & 0.031 & $* *$ \\
\hline & $(0.007)$ & $(0.009)$ & & $(0.013)$ & \\
\hline \multirow[t]{2}{*}{ Youth female } & -0.037 & 0.008 & & -0.027 & \\
\hline & $(0.021)$ & $(0.033)$ & & $(0.044)$ & \\
\hline \multirow[t]{2}{*}{ Prime-aged female } & -0.001 & 0.045 & $* *$ & 0.059 & $*$ \\
\hline & $(0.008)$ & $(0.018)$ & & $(0.030)$ & \\
\hline
\end{tabular}

Note: $*$ significant at $10 \%, * *$ significant at $5 \%, * * *$ significant at $1 \%$. 
Table 4.1. Relationship between Older Persons' Employment and Youth Wages and Earnings (Both Sexes)

\begin{tabular}{|c|c|c|c|c|}
\hline & \multicolumn{2}{|c|}{ Wage $(\log )$} & \multicolumn{2}{|c|}{ Total earnings $(\log )$} \\
\hline & \multicolumn{2}{|c|}{ (1) } & \multicolumn{2}{|c|}{ (2) } \\
\hline \multirow[t]{2}{*}{ Older persons' employment rate } & 0.008 & & 0.123 & $*$ \\
\hline & $(0.073)$ & & $(0.067)$ & \\
\hline \multirow[t]{2}{*}{ Fraction of black in state } & -0.543 & & -0.527 & $*$ \\
\hline & $(0.332)$ & & $(0.300)$ & \\
\hline \multirow[t]{2}{*}{ Fraction of less than high school in state } & -0.415 & $* * *$ & -0.508 & $* * *$ \\
\hline & $(0.147)$ & & $(0.154)$ & \\
\hline \multirow[t]{2}{*}{ State average unemployment rate } & -0.159 & $* *$ & -0.643 & $* * *$ \\
\hline & $(0.151)$ & & $(0.235)$ & \\
\hline \multirow[t]{2}{*}{ Fraction of poor in state } & -0.514 & & -1.913 & $* * *$ \\
\hline & $(0.239)$ & & $(0.295)$ & \\
\hline \multirow[t]{2}{*}{ Percent of population $20-24$} & -0.108 & & 0.600 & $*$ \\
\hline & $(0.226)$ & & $(0.329)$ & \\
\hline \multirow[t]{2}{*}{ Percent of jobs in manufacturing } & -0.261 & & 0.105 & \\
\hline & $(0.167)$ & & $(0.184)$ & \\
\hline \multirow[t]{2}{*}{ Percent of jobs in service industry } & -0.099 & & -0.630 & $* * *$ \\
\hline & $(0.192)$ & & $(0.220)$ & \\
\hline \multirow[t]{2}{*}{ Percent of jobs in self-employment } & -0.210 & & -0.899 & $* * *$ \\
\hline & $(0.195)$ & & $(0.200)$ & \\
\hline \multirow[t]{2}{*}{ Housing price index growth } & -0.162 & $* *$ & 0.030 & \\
\hline & $(0.069)$ & & $(0.079)$ & \\
\hline \multirow[t]{2}{*}{ GSP per capita (log) } & 0.223 & $* * *$ & 0.251 & $* * *$ \\
\hline & $(0.042)$ & & $(0.039)$ & \\
\hline \multirow[t]{2}{*}{ GSP growth (percent) } & -0.183 & & -0.161 & $*$ \\
\hline & $(0.115)$ & & $(0.091)$ & \\
\hline \multirow[t]{2}{*}{ Great Recession indicator } & -0.071 & $* *$ & -0.146 & $* * *$ \\
\hline & $(0.029)$ & & $(0.023)$ & \\
\hline Year dummies & Yes & & Yes & \\
\hline State dummies & Yes & & Yes & \\
\hline R squared & 0.541 & & 0.633 & \\
\hline Number of observations & 1683 & & 1683 & \\
\hline
\end{tabular}

Note: * significant at 10\%, ** significant at 5\%,*** significant at $1 \%$. 
Table 4.1. Relationship between Older Persons' Employment and Prime-aged Wages and Earnings (Both Sexes) (cont'd)

\begin{tabular}{|c|c|c|c|c|}
\hline & \multicolumn{2}{|c|}{ Wage $(\log )$} & \multicolumn{2}{|c|}{ Total earnings $(\log )$} \\
\hline & \multicolumn{2}{|c|}{ (1) } & \multicolumn{2}{|c|}{ (2) } \\
\hline \multirow[t]{2}{*}{ Older persons' employment rate } & 0.078 & ** & 0.114 & **** \\
\hline & $(0.034)$ & & $(0.039)$ & \\
\hline \multirow[t]{2}{*}{ Fraction of black in state } & -0.385 & * & -0.274 & \\
\hline & $(0.196)$ & & $(0.191)$ & \\
\hline \multirow[t]{2}{*}{ Fraction of less than high school in state } & -0.601 & **** & -0.918 & $* * *$ \\
\hline & $(0.074)$ & & $(0.081)$ & \\
\hline \multirow[t]{2}{*}{ State average unemployment rate } & 0.354 & **** & -0.462 & $* * *$ \\
\hline & $(0.116)$ & & $(0.156)$ & \\
\hline \multirow[t]{2}{*}{ Fraction of poor in state } & -0.134 & & -0.471 & $* * *$ \\
\hline & $(0.093)$ & & $(0.109)$ & \\
\hline \multirow[t]{2}{*}{ Percent of population $25-54$} & 0.263 & ** & 0.268 & ** \\
\hline & $(0.108)$ & & $(0.108)$ & \\
\hline \multirow[t]{2}{*}{ Percent of jobs in manufacturing } & -0.299 & ** & -0.167 & \\
\hline & $(0.121)$ & & $(0.146)$ & \\
\hline \multirow{2}{*}{ Percent of jobs in service industry } & -0.001 & & 0.020 & \\
\hline & $(0.116)$ & & $(0.120)$ & \\
\hline \multirow[t]{2}{*}{ Percent of jobs in self-employment } & 0.243 & **** & -0.556 & $* * *$ \\
\hline & $(0.091)$ & & $(0.110)$ & \\
\hline \multirow[t]{2}{*}{ Housing price index growth } & -0.084 & **** & -0.056 & * \\
\hline & $(0.030)$ & & $(0.031)$ & \\
\hline \multirow[t]{2}{*}{ GSP per capita $(\log )$} & 0.196 & $* * *$ & 0.166 & $* * *$ \\
\hline & $(0.027)$ & & $(0.033)$ & \\
\hline \multirow[t]{2}{*}{ GSP growth (percent) } & -0.128 & $* * *$ & -0.067 & \\
\hline & $(0.043)$ & & $(0.052)$ & \\
\hline \multirow[t]{2}{*}{ Great Recession indicator } & -0.046 & *** & -0.084 & $* * *$ \\
\hline & $(0.013)$ & & $(0.011)$ & \\
\hline Year dummies & Yes & & Yes & \\
\hline State dummies & Yes & & Yes & \\
\hline R squared & 0.898 & & 0.933 & \\
\hline Number of observations & 1683 & & 1683 & \\
\hline
\end{tabular}

Note: * significant at 10\%, ** significant at 5\%, *** significant at $1 \%$. 
Table 4.2. Relationship between Older Persons' Employment and Youth and Prime-aged Wages and Earnings (by Gender)

\begin{tabular}{|c|c|c|c|}
\hline & Wage (log) & \multicolumn{2}{|c|}{ Total earnings $(\log )$} \\
\hline \multirow[t]{2}{*}{ Youth male } & -0.004 & 0.197 & $* *$ \\
\hline & $(0.073)$ & $(0.087)$ & \\
\hline \multirow[t]{2}{*}{ Prime-aged male } & 0.042 & 0.064 & $* *$ \\
\hline & $(0.023)$ & $(0.033)$ & \\
\hline \multirow[t]{2}{*}{ Youth female } & -0.020 & -0.028 & \\
\hline & $(0.067)$ & $(0.075)$ & \\
\hline \multirow[t]{2}{*}{ Prime-aged female } & 0.020 & 0.106 & $* *$ \\
\hline & $(0.035)$ & $(0.047)$ & \\
\hline
\end{tabular}

Note: $*$ significant at $10 \%, * *$ significant at $5 \%, * * *$ significant at $1 \%$. 
Table 5.1. Test Differential Relationship between Older Persons' Employment and Youth Labor Market Activity and Wages During the Great Recession (Both Sexes)

\begin{tabular}{|c|c|c|c|c|c|c|c|c|c|c|c|c|c|c|c|c|}
\hline \multirow{3}{*}{ Older persons' EMP rate } & \multicolumn{4}{|c|}{ Unemployment } & \multicolumn{4}{|c|}{ Employment } & \multicolumn{4}{|c|}{ Hours worked $(\log )$} & \multicolumn{4}{|c|}{ Wage rate $(\log )$} \\
\hline & \multicolumn{4}{|c|}{ Interaction $^{+}$} & \multicolumn{4}{|c|}{ Interaction $^{+}$} & \multicolumn{5}{|c|}{ Interaction $^{+}$} & \multicolumn{3}{|c|}{ Interaction $^{+}$} \\
\hline & -0.021 & & 0.080 & & 0.062 & $*$ & -0.055 & & 0.043 & & 0.041 & & -0.006 & & 0.278 & $*$ \\
\hline & $(0.024)$ & & $(0.073)$ & & $(0.033)$ & & $(0.072)$ & & $(0.034)$ & & $(0.112)$ & & $(0.079)$ & & $(0.163)$ & \\
\hline \multirow[t]{2}{*}{ Local average wage (youth) } & -0.021 & ** & 0.059 & $* *$ & 0.015 & & -0.069 & $*$ & -0.016 & & 0.015 & & - & & - & \\
\hline & $(0.009)$ & & $(0.025)$ & & $(0.013)$ & & $(0.036)$ & & $(0.018)$ & & $(0.056)$ & & & & & \\
\hline \multirow[t]{2}{*}{ Fraction of black in state } & 0.113 & & 0.022 & & -0.203 & $*$ & 0.042 & & -0.084 & & 0.030 & & -0.603 & & -0.066 & \\
\hline & $(0.080)$ & & $(0.051)$ & & $(0.106)$ & & $(0.057)$ & & $(0.118)$ & & $(0.083)$ & & $(0.368)$ & & $(0.092)$ & \\
\hline \multirow[t]{2}{*}{ Fraction of less than high school in state } & -0.015 & & 0.023 & & 0.015 & & 0.081 & & -0.109 & & 0.189 & & -0.455 & $* * *$ & 0.375 & \\
\hline & $(0.051)$ & & $(0.087)$ & & $(0.061)$ & & $(0.104)$ & & $(0.093)$ & & $(0.187)$ & & $(0.145)$ & & $(0.235)$ & \\
\hline \multirow[t]{2}{*}{ Fraction of poor in state } & 0.275 & $* * *$ & 0.239 & $* *$ & -0.309 & $* * *$ & -0.488 & $* *$ & -0.293 & $*$ & -0.556 & $*$ & -0.144 & & 0.259 & \\
\hline & $(0.062)$ & & $(0.105)$ & & $(0.112)$ & & $(0.192)$ & & $(0.160)$ & & $(0.298)$ & & $(0.165)$ & & $(0.419)$ & \\
\hline \multirow[t]{2}{*}{ Percent of population $20-24$} & -0.036 & & -0.161 & & 0.178 & & -0.191 & & 0.342 & $* *$ & 0.566 & & -0.204 & & 1.556 & $*$ \\
\hline & $(0.100)$ & & $(0.303)$ & & $(0.138)$ & & $(0.426)$ & & $(0.159)$ & & $(0.641)$ & & $(0.238)$ & & $(0.871)$ & \\
\hline \multirow[t]{2}{*}{ State average unemployment rate } & - & & - & & - & & - & & -0.864 & $* * *$ & 0.600 & & -0.332 & & -0.351 & \\
\hline & & & & & & & & & $(0.155)$ & & $(0.410)$ & & $(0.224)$ & & $(0.717)$ & \\
\hline \multirow[t]{2}{*}{ Percent of jobs in manufacturing } & -0.034 & & 0.298 & $* * *$ & 0.261 & $* * *$ & -0.306 & $* *$ & 0.185 & $*$ & -0.546 & $* * *$ & -0.331 & $* *$ & -0.519 & \\
\hline & $(0.066)$ & & $(0.104)$ & & $(0.084)$ & & $(0.141)$ & & $(0.094)$ & & $(0.165)$ & & $(0.164)$ & & $(0.339)$ & \\
\hline \multirow[t]{2}{*}{ Percent of jobs in service industry } & 0.011 & & 0.041 & & 0.041 & & -0.111 & & -0.313 & $* * *$ & -0.300 & & -0.036 & & -0.088 & \\
\hline & $(0.055)$ & & $(0.095)$ & & $(0.077)$ & & $(0.112)$ & & $(0.106)$ & & $(0.221)$ & & (0.189) & & $(0.250)$ & \\
\hline
\end{tabular}




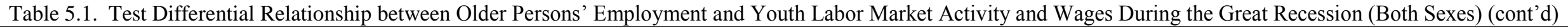

\begin{tabular}{|c|c|c|c|c|c|c|c|c|c|c|c|c|}
\hline \multirow{3}{*}{ Percent of jobs in self-employment } & \multicolumn{3}{|c|}{ Unemployment } & \multicolumn{3}{|c|}{ Employment } & \multicolumn{3}{|c|}{ Hours worked $(\log )$} & \multicolumn{3}{|c|}{ Wage rate $(\log )$} \\
\hline & \multicolumn{3}{|c|}{ Interaction $^{+}$} & \multicolumn{3}{|c|}{ Interaction $^{+}$} & \multicolumn{3}{|c|}{ Interaction $^{+}$} & \multicolumn{3}{|c|}{ Interaction $^{+}$} \\
\hline & -0.114 & & 0.055 & -0.205 & $* *$ & 0.043 & -0.208 & -0.412 & & -0.174 & & 0.491 \\
\hline \multirow[t]{2}{*}{ Housing price index growth } & -0.156 & $* * *$ & -0.012 & 0.180 & $* * *$ & 0.022 & 0.070 & 0.232 & & -0.185 & $* *$ & 0.232 \\
\hline & $(0.025)$ & & $(0.086)$ & $(0.031)$ & & $(0.127)$ & $(0.038)$ & $(0.149)$ & & $(0.074)$ & & $(0.286)$ \\
\hline \multirow[t]{2}{*}{ GSP per capita (log) } & 0.009 & & -0.001 & 0.010 & & 0.000 & 0.029 & -0.013 & $*$ & 0.225 & $* * *$ & -0.001 \\
\hline & $(0.010)$ & & $(0.003)$ & $(0.017)$ & & $(0.004)$ & $(0.033)$ & $(0.007)$ & & $(0.040)$ & & $(0.008)$ \\
\hline \multirow[t]{2}{*}{ GSP growth (percent) } & -0.055 & & -0.018 & -0.034 & & 0.129 & -0.077 & 0.249 & & -0.172 & & 0.004 \\
\hline & $(0.044)$ & & $(0.144)$ & $(0.044)$ & & $(0.190)$ & $(0.050)$ & $(0.185)$ & & $(0.118)$ & & $(0.621)$ \\
\hline Great Recession indicator & -0.239 & $*$ & - & 0.310 & $*$ & - & 0.253 & - & & -0.386 & & - \\
\hline Year dummies & Yes & & & Yes & & & Yes & & & Yes & & \\
\hline State dummies & Yes & & & Yes & & & Yes & & & Yes & & \\
\hline $\mathrm{R}$ squared & 0.514 & & & 0.613 & & & 0.739 & & & 0.549 & & \\
\hline Number of observations & 1683 & & & 1683 & & & 1683 & & & 1683 & & \\
\hline
\end{tabular}


Table 5.1. Test Differential Relationship between Older Persons' Employment and Prime-aged Labor Market Activity and Wages During the Great Recession (Both Sexes) (cont'd)

\begin{tabular}{|c|c|c|c|c|c|c|c|c|c|c|c|c|c|c|c|c|}
\hline \multirow{3}{*}{ Older persons' EMP rate } & \multicolumn{4}{|c|}{ Unemployment } & \multicolumn{4}{|c|}{ Employment } & \multicolumn{4}{|c|}{ Hours worked (log) } & \multicolumn{4}{|c|}{ Wage rate $(\log )$} \\
\hline & \multicolumn{4}{|c|}{ Interaction $^{+}$} & \multicolumn{4}{|c|}{ Interaction $^{+}$} & \multicolumn{4}{|c|}{ Interaction $^{+}$} & \multicolumn{4}{|c|}{ Interaction $^{+}$} \\
\hline & -0.008 & & -0.015 & & 0.037 & $* * *$ & 0.032 & & 0.013 & & 0.074 & & 0.085 & $* * *$ & -0.203 & $* *$ \\
\hline & $(0.008)$ & & $(0.030)$ & & $(0.013)$ & & $(0.041)$ & & $(0.017)$ & & $(0.049)$ & & $(0.032)$ & & $(0.083)$ & \\
\hline \multirow[t]{2}{*}{ Local average wage (prime-aged) } & 0.023 & $* * *$ & -0.025 & & -0.054 & $* * *$ & 0.021 & & -0.021 & & -0.010 & & - & & - & \\
\hline & $(0.008)$ & & $(0.016)$ & & $(0.019)$ & & $(0.028)$ & & $(0.016)$ & & $(0.030)$ & & & & & \\
\hline \multirow[t]{2}{*}{ Fraction of black in state } & 0.003 & & 0.019 & & 0.020 & & -0.012 & & 0.062 & & -0.025 & & -0.379 & $* *$ & -0.080 & \\
\hline & $(0.026)$ & & $(0.016)$ & & $(0.061)$ & & $(0.020)$ & & $(0.046)$ & & $(0.026)$ & & $(0.178)$ & & $(0.056)$ & \\
\hline \multirow[t]{2}{*}{ Fraction of less than high school in state } & 0.038 & $* * *$ & 0.022 & & -0.119 & $* * *$ & 0.025 & & -0.178 & $* * *$ & 0.071 & & -0.577 & $* * *$ & 0.004 & \\
\hline & $(0.014)$ & & $(0.037)$ & & $(0.031)$ & & $(0.048)$ & & $(0.046)$ & & $(0.049)$ & & $(0.075)$ & & $(0.131)$ & \\
\hline \multirow[t]{2}{*}{ Fraction of poor in state } & 0.178 & $* * *$ & -0.035 & & -0.294 & $* * *$ & -0.084 & & -0.226 & $* * *$ & -0.168 & $*$ & -0.117 & & 0.032 & \\
\hline & $(0.030)$ & & $(0.066)$ & & $(0.052)$ & & $(0.089)$ & & $(0.057)$ & & $(0.099)$ & & $(0.087)$ & & $(0.197)$ & \\
\hline \multirow[t]{2}{*}{ Percent of population } & -0.005 & & 0.010 & & -0.003 & & -0.011 & & 0.004 & & -0.010 & & 0.294 & $* * *$ & 0.139 & \\
\hline & $(0.020)$ & & $(0.054)$ & & $(0.036)$ & & $(0.071)$ & & $(0.054)$ & & $(0.085)$ & & $(0.103)$ & & $(0.187)$ & \\
\hline \multirow[t]{2}{*}{ State average unemployment rate } & - & & - & & - & & - & & -0.549 & $* * *$ & 0.082 & & 0.528 & $* * *$ & -0.688 & $* * *$ \\
\hline & & & & & & & & & $(0.073)$ & & $(0.134)$ & & $(0.117)$ & & $(0.202)$ & \\
\hline \multirow[t]{2}{*}{ Percent of jobs in manufacturing } & -0.051 & $* *$ & 0.166 & $* * *$ & 0.105 & $* *$ & -0.129 & $* * *$ & -0.079 & $*$ & -0.126 & $* *$ & -0.377 & $* * *$ & -0.003 & \\
\hline & $(0.019)$ & & $(0.036)$ & & $(0.041)$ & & $(0.044)$ & & $(0.046)$ & & $(0.057)$ & & $(0.112)$ & & $(0.135)$ & \\
\hline \multirow[t]{2}{*}{ Percent of jobs in service industry } & -0.034 & & 0.083 & $* *$ & 0.060 & & 0.011 & & -0.131 & $* * *$ & 0.167 & $* *$ & -0.011 & & 0.406 & $* * *$ \\
\hline & $(0.023)$ & & $(0.038)$ & & $(0.040)$ & & $(0.054)$ & & $(0.043)$ & & $(0.066)$ & & $(0.118)$ & & $(0.149)$ & \\
\hline
\end{tabular}


Table 5.1. Test Differential Relationship between Older Persons' Employment and Prime-aged Labor Market Activity and Wages During the Great Recession (Both Sexes) (cont'd)

\begin{tabular}{|c|c|c|c|c|c|c|c|c|c|c|c|c|c|c|c|}
\hline \multirow{3}{*}{ Percent of jobs in self-employment } & \multicolumn{4}{|c|}{ Unemployment } & \multicolumn{4}{|c|}{ Employment } & \multicolumn{3}{|c|}{ Hours worked $(\log )$} & \multicolumn{4}{|c|}{ Wage rate $(\log )$} \\
\hline & \multicolumn{4}{|c|}{ Interaction $^{+}$} & \multicolumn{4}{|c|}{ Interaction $^{+}$} & \multicolumn{3}{|c|}{ Interaction $^{+}$} & \multicolumn{4}{|c|}{ Interaction ${ }^{+}$} \\
\hline & $\begin{array}{r}-0.048 \\
(0.025)\end{array}$ & $*$ & $\begin{array}{r}0.014 \\
(0.073)\end{array}$ & & $\begin{array}{r}-0.057 \\
(0.050)\end{array}$ & & $\begin{array}{r}0.178 \\
(0.104)\end{array}$ & $*$ & $\begin{array}{r}0.014 \\
(0.059)\end{array}$ & $\begin{array}{r}-0.096 \\
(0.100)\end{array}$ & & $\begin{array}{r}0.212 \\
(0.092)\end{array}$ & $* *$ & $\begin{array}{r}0.608 \\
(0.273)\end{array}$ & $* *$ \\
\hline Housing price index growth & $\begin{array}{r}-0.070 \\
(0.009)\end{array}$ & $* * *$ & $\begin{array}{r}-0.089 \\
(0.035)\end{array}$ & $* *$ & $\begin{array}{r}0.042 \\
(0.015)\end{array}$ & $* * *$ & $\begin{array}{r}0.133 \\
(0.045)\end{array}$ & $* * *$ & $\begin{array}{c}-0.015 \\
(0.020)\end{array}$ & $\begin{array}{r}0.224 \\
(0.067)\end{array}$ & $* * *$ & $\begin{array}{r}-0.073 \\
(0.034)\end{array}$ & $* *$ & $\begin{array}{r}0.144 \\
(0.102)\end{array}$ & \\
\hline GSP per capita (log) & $\begin{array}{r}-0.005 \\
(0.004)\end{array}$ & & $\begin{array}{r}0.002 \\
(0.002)\end{array}$ & & $\begin{array}{r}0.002 \\
(0.011)\end{array}$ & & $\begin{array}{r}0.000 \\
(0.002)\end{array}$ & & $\begin{array}{r}-0.009 \\
(0.012)\end{array}$ & $\begin{array}{r}0.001 \\
(0.003)\end{array}$ & & $\begin{array}{r}0.191 \\
(0.025)\end{array}$ & $* * *$ & $\begin{array}{c}-0.011 \\
(0.005)\end{array}$ & $* *$ \\
\hline GSP growth (percent) & $\begin{array}{r}-0.035 \\
(0.027)\end{array}$ & & $\begin{array}{r}0.102 \\
(0.065)\end{array}$ & & $\begin{array}{r}0.019 \\
(0.034)\end{array}$ & & $\begin{array}{c}-0.004 \\
(0.084)\end{array}$ & & $\begin{array}{c}-0.019 \\
(0.020)\end{array}$ & $\begin{array}{r}0.139 \\
(0.073)\end{array}$ & $*$ & $\begin{array}{r}-0.131 \\
(0.041)\end{array}$ & $* * *$ & $\begin{array}{r}0.296 \\
(0.157)\end{array}$ & $*$ \\
\hline Great Recession indicator & $\begin{array}{r}0.012 \\
(0.079)\end{array}$ & & - & & $\begin{array}{c}-0.111 \\
(0.112)\end{array}$ & & - & & $\begin{array}{r}-0.087 \\
(0.111)\end{array}$ & - & & $\begin{array}{r}-0.055 \\
(0.242)\end{array}$ & & - & \\
\hline Year dummies & Yes & & & & Yes & & & & Yes & & & Yes & & & \\
\hline State dummies & Yes & & & & Yes & & & & Yes & & & Yes & & & \\
\hline $\mathrm{R}$ squared & 0.752 & & & & 0.860 & & & & 0.872 & & & 0.902 & & & \\
\hline Number of observations & 1683 & & & & 1683 & & & & 1683 & & & 1683 & & & \\
\hline
\end{tabular}


Table 5.2. Test Differential Relationship between Older Persons' Employment and Youth and Prime-aged Labor Market Activity and Wages During the Great Recession (by Gender)

\begin{tabular}{|c|c|c|c|c|c|c|c|c|}
\hline & \multicolumn{2}{|c|}{ Unemployment } & \multicolumn{2}{|c|}{ Employment } & \multicolumn{2}{|c|}{ Hours worked $(\log )$} & \multicolumn{2}{|c|}{ Wage (log) } \\
\hline & $\begin{array}{l}\text { Older persons' } \\
\text { employment rate }\end{array}$ & Interaction $^{+}$ & $\begin{array}{l}\text { Older persons' } \\
\text { employment rate }\end{array}$ & Interaction $^{+}$ & $\begin{array}{l}\text { Older persons' } \\
\text { employment rate }\end{array}$ & Interaction $^{+}$ & $\begin{array}{l}\text { Older persons' } \\
\text { employment rate }\end{array}$ & Interaction $^{+}$ \\
\hline \multirow[t]{2}{*}{ Youth male } & -0.017 & 0.083 & 0.062 & -0.112 & $0.124 * * *$ & -0.077 & -0.021 & $0.547 * *$ \\
\hline & $(0.029)$ & $(0.090)$ & $(0.038)$ & $(0.101)$ & $(0.044)$ & $(0.127)$ & $(0.077)$ & $(0.237)$ \\
\hline \multirow[t]{2}{*}{ Prime-aged male } & -0.006 & -0.001 & $0.020 *$ & 0.049 & $0.027 * *$ & 0.016 & 0.039 & -0.125 \\
\hline & $(0.007)$ & $(0.037)$ & $(0.009)$ & $(0.046)$ & $(0.012)$ & $(0.047)$ & $(0.024)$ & $(0.116)$ \\
\hline \multirow[t]{2}{*}{ Youth female } & $-0.047 *$ & $0.127 *$ & 0.002 & 0.077 & -0.038 & 0.233 & 0.010 & -0.065 \\
\hline & $(0.023)$ & $(0.073)$ & $(0.034)$ & $(0.097)$ & $(0.043)$ & $(0.203)$ & $(0.073)$ & $(0.238)$ \\
\hline \multirow[t]{2}{*}{ Prime-aged female } & -0.001 & 0.013 & $0.047 * *$ & -0.049 & $0.058 *$ & 0.025 & 0.037 & $-0.267 * * *$ \\
\hline & $(0.008)$ & $(0.023)$ & $(0.018)$ & $(0.042)$ & $(0.030)$ & $(0.061)$ & $(0.034)$ & $(0.093)$ \\
\hline
\end{tabular}

Notes : ${ }^{+}$Interaction with the Great Recession indicator. * significant at $10 \%, * *$ significant at $5 \%, * * *$ significant at $1 \%$. 
Table 6.1. Relationship between Low-educated Older Persons’ Employment and Low-educated Youth (Both Sexes)

\begin{tabular}{|c|c|c|c|c|}
\hline & UE & EMP & Hours worked $(\log )$ & Wage $(\log )$ \\
\hline \multirow[t]{2}{*}{ Older persons' EMP rate } & -0.035 & $0.073 *$ & 0.065 & 0.016 \\
\hline & $(0.036)$ & $(0.038)$ & $(0.049)$ & $(0.074)$ \\
\hline \multirow[t]{2}{*}{ Older persons' EMP rate * Great Recession indicator } & -0.009 & 0.053 & $0.277 * *$ & -0.009 \\
\hline & $(0.053)$ & $(0.070)$ & $(0.114)$ & $(0.155)$ \\
\hline \multirow[t]{2}{*}{ Local average wage of young } & -0.006 & -0.004 & -0.006 & - \\
\hline & $(0.012)$ & $(0.012)$ & $(0.015)$ & \\
\hline \multirow[t]{2}{*}{ Fraction of black in state } & 0.051 & -0.234 & -0.105 & -0.384 \\
\hline & $(0.090)$ & $(0.166)$ & $(0.189)$ & $(0.233)$ \\
\hline \multirow[t]{2}{*}{ Fraction of less than high school in state } & $-0.125 *$ & 0.051 & -0.047 & -0.292 \\
\hline & $(0.069)$ & $(0.077)$ & $(0.108)$ & $(0.178)$ \\
\hline \multirow[t]{2}{*}{ Fraction of poor in state } & $0.402 * * *$ & $-0.523 * * *$ & $-0.520 * *$ & $-0.453 * *$ \\
\hline & $(0.085)$ & $(0.103)$ & $(0.199)$ & $(0.226)$ \\
\hline \multirow[t]{2}{*}{ Percent of population $20-24$} & -0.069 & 0.252 & $0.478 * *$ & 0.045 \\
\hline & $(0.131)$ & $(0.160)$ & $(0.193)$ & $(0.380)$ \\
\hline \multirow[t]{2}{*}{ State average unemployment rate } & - & - & $-1.012 * * *$ & -0.443 \\
\hline & & & $(0.174)$ & $(0.292)$ \\
\hline \multirow[t]{2}{*}{ Percent of jobs in manufacturing } & -0.109 & $0.258 * *$ & 0.133 & $-0.311 *$ \\
\hline & $(0.085)$ & $(0.100)$ & $(0.131)$ & $(0.164)$ \\
\hline \multirow[t]{2}{*}{ Percent of jobs in service industry } & 0.029 & -0.017 & $-0.399 * * *$ & -0.326 \\
\hline & $(0.075)$ & $(0.115)$ & $(0.138)$ & $(0.200)$ \\
\hline \multirow[t]{2}{*}{ Percent of jobs in self-employment } & $-0.176 *$ & -0.028 & -0.236 & -0.275 \\
\hline & $(0.105)$ & $(0.152)$ & $(0.256)$ & $(0.274)$ \\
\hline \multirow[t]{2}{*}{ Housing price index growth } & $-0.203 * * *$ & $0.160 * * *$ & $0.097 *$ & $-0.157 * *$ \\
\hline & $(0.033)$ & $(0.035)$ & $(0.054)$ & $(0.073)$ \\
\hline \multirow[t]{2}{*}{ GSP per capita (log) } & -0.008 & 0.025 & 0.011 & $0.218 * * *$ \\
\hline & $(0.012)$ & $(0.023)$ & $(0.040)$ & $(0.040)$ \\
\hline \multirow[t]{2}{*}{ GSP growth (percent) } & -0.060 & -0.029 & $-0.157 * * *$ & -0.133 \\
\hline & $(0.051)$ & $(0.047)$ & $(0.044)$ & $(0.115)$ \\
\hline \multirow[t]{2}{*}{ Great Recession indicator } & 0.050 & $-0.106 * *$ & $-0.150 * *$ & -0.009 \\
\hline & $(0.040)$ & $(0.047)$ & $(0.066)$ & 0.107 \\
\hline Year dummies & Yes & Yes & Yes & Yes \\
\hline State dummies & Yes & Yes & Yes & Yes \\
\hline R squared & 0.414 & 0.548 & 0.665 & 0.370 \\
\hline Number of observations & 1613 & 1613 & 1647 & 1647 \\
\hline
\end{tabular}

Note: $*$ significant at $10 \%, * *$ significant at $5 \%, * * *$ significant at $1 \%$. All variables refer only to low-educated individuals. 
Table 6.1. The Relationship between Low-educated Older Persons' Employment and Low-educated Primeaged (Both Sexes) (cont'd)

\begin{tabular}{|c|c|c|c|c|}
\hline & $\mathrm{UE}$ & EMP & Hours worked $(\log )$ & Wage $(\log )$ \\
\hline \multirow[t]{2}{*}{ Older persons' EMP rate } & -0.015 & 0.021 & 0.008 & -0.014 \\
\hline & $(0.013)$ & $(0.018)$ & $(0.022)$ & $(0.038)$ \\
\hline \multirow[t]{2}{*}{ Older persons' EMP rate * Great Recession indicator } & -0.039 & $0.070 * *$ & $0.113 * *$ & 0.046 \\
\hline & $(0.023)$ & $(0.030)$ & $(0.046)$ & $(0.080)$ \\
\hline \multirow[t]{2}{*}{ Local average wage of prime-aged } & -0.002 & -0.009 & -0.011 & - \\
\hline & $(0.008)$ & $(0.012)$ & $(0.017)$ & \\
\hline \multirow[t]{2}{*}{ Fraction of black in state } & -0.053 & 0.110 & $0.275 *$ & -0.181 \\
\hline & $(0.066)$ & $(0.152)$ & $(0.145)$ & $(0.138)$ \\
\hline \multirow[t]{2}{*}{ Fraction of less than high school in state } & $-0.059 * *$ & 0.059 & -0.020 & $-0.341 * * *$ \\
\hline & $(0.025)$ & $(0.039)$ & $(0.060)$ & $(0.103)$ \\
\hline \multirow[t]{2}{*}{ Fraction of poor in state } & $0.229 * * *$ & $-0.390 * * *$ & $-0.364 * * *$ & $-0.375 * * *$ \\
\hline & $(0.043)$ & $(0.077)$ & $(0.091)$ & $(0.108)$ \\
\hline \multirow[t]{2}{*}{ Percent of population 25-54 } & 0.003 & -0.011 & 0.026 & 0.099 \\
\hline & $(0.030)$ & $(0.044)$ & $(0.074)$ & $(0.113)$ \\
\hline \multirow[t]{2}{*}{ State average unemployment rate } & - & - & $-0.780 * * *$ & 0.188 \\
\hline & & & $(0.098)$ & $(0.166)$ \\
\hline \multirow[t]{2}{*}{ Percent of jobs in manufacturing } & $-0.099 * * *$ & $0.181 * * *$ & -0.030 & $-0.322 * *$ \\
\hline & $(0.031)$ & $(0.057)$ & $(0.075)$ & $(0.126)$ \\
\hline \multirow[t]{2}{*}{ Percent of jobs in service industry } & -0.056 & 0.035 & $-0.155 * *$ & -0.144 \\
\hline & $(0.036)$ & $(0.076)$ & $(0.067)$ & $(0.092)$ \\
\hline \multirow[t]{2}{*}{ Percent of jobs in self-employment } & -0.036 & 0.021 & 0.093 & 0.099 \\
\hline & $(0.036)$ & $(0.062)$ & $(0.074)$ & $(0.127)$ \\
\hline \multirow[t]{2}{*}{ Housing price index growth } & $-0.105 * * *$ & $0.077 * * *$ & 0.001 & -0.065 \\
\hline & $(0.012)$ & $(0.017)$ & $(0.024)$ & $(0.041)$ \\
\hline \multirow[t]{2}{*}{ GSP per capita (log) } & -0.008 & 0.000 & -0.010 & $0.167 * * *$ \\
\hline & $(0.005)$ & $(0.012)$ & $(0.016)$ & $(0.022)$ \\
\hline \multirow[t]{2}{*}{ GSP growth (percent) } & -0.045 & 0.013 & -0.016 & $-0.157 * * *$ \\
\hline & $(0.033)$ & $(0.042)$ & $(0.030)$ & $(0.056)$ \\
\hline \multirow[t]{2}{*}{ Great Recession indicator } & $0.075 * * *$ & $-0.106 * * *$ & $-0.075 * *$ & -0.055 \\
\hline & $(0.014)$ & $(0.022)$ & $(0.032)$ & $(0.050)$ \\
\hline Year dummies & Yes & Yes & Yes & Yes \\
\hline State dummies & Yes & Yes & Yes & Yes \\
\hline R squared & 0.690 & 0.777 & 0.825 & 0.706 \\
\hline Number of observations & 1614 & 1617 & 1647 & 1647 \\
\hline
\end{tabular}

Note: $*$ significant at $10 \%, * *$ significant at $5 \%, * * *$ significant at $1 \%$. All variables refer only to low-educated individuals. 
Table 6.2. Relationship between High-educated Older Persons' Employment and High-educated Youth (Both Sexes)

\begin{tabular}{|c|c|c|c|c|}
\hline & UE & EMP & Hours worked $(\log )$ & Wage $(\log )$ \\
\hline Older persons' EMP rate & $\begin{array}{r}0.008 \\
(0.016)\end{array}$ & $\begin{array}{r}0.000 \\
(0.026)\end{array}$ & $\begin{array}{r}0.005 \\
(0.035)\end{array}$ & $\begin{array}{r}0.024 \\
(0.051)\end{array}$ \\
\hline Older persons' EMP rate * Great Recession indicator & $\begin{array}{r}0.035 \\
(0.063)\end{array}$ & $\begin{array}{r}0.028 \\
(0.065)\end{array}$ & $\begin{array}{r}0.099 \\
(0.137)\end{array}$ & $\begin{array}{l}0.510 * * * \\
(0.143)\end{array}$ \\
\hline Local average wage of young & $\begin{array}{l}-0.019 * * \\
(0.008)\end{array}$ & $\begin{array}{r}0.012 \\
(0.012)\end{array}$ & $\begin{array}{r}-0.012 \\
(0.018)\end{array}$ & - \\
\hline Fraction of black in state & $\begin{array}{r}0.023 \\
(0.041)\end{array}$ & $\begin{array}{r}0.017 \\
(0.120)\end{array}$ & $\begin{array}{r}0.116 \\
(0.162)\end{array}$ & $\begin{array}{l}-0.570 * \\
(0.309)\end{array}$ \\
\hline Fraction of less than high school in state & $\begin{array}{r}-0.046 \\
(0.050)\end{array}$ & $\begin{array}{r}-0.007 \\
(0.091)\end{array}$ & $\begin{array}{l}-0.210 * \\
(0.122)\end{array}$ & $\begin{array}{r}-0.224 \\
(0.170)\end{array}$ \\
\hline Fraction of poor in state & $\begin{array}{l}0.147 * * \\
(0.057)\end{array}$ & $\begin{array}{l}-0.338 * * \\
(0.136)\end{array}$ & $\begin{array}{r}-0.211 \\
(0.191)\end{array}$ & $\begin{array}{r}-0.058 \\
(0.185)\end{array}$ \\
\hline Percent of population $20-24$ & - & - & - & - \\
\hline State average unemployment rate & - & - & $\begin{array}{l}-0.744 * * * \\
(0.192)\end{array}$ & $\begin{array}{l}-0.663 * * \\
(0.254)\end{array}$ \\
\hline Percent of jobs in manufacturing & $\begin{array}{r}-0.057 \\
(0.050)\end{array}$ & $\begin{array}{l}0.216 * * \\
(0.088)\end{array}$ & $\begin{array}{r}0.124 \\
(0.113)\end{array}$ & $\begin{array}{r}-0.214 \\
(0.213)\end{array}$ \\
\hline Percent of jobs in service industry & $\begin{array}{r}-0.027 \\
(0.070)\end{array}$ & $\begin{array}{r}0.058 \\
(0.110)\end{array}$ & $\begin{array}{l}-0.385 * * * \\
(0.134)\end{array}$ & $\begin{array}{r}-0.019 \\
(0.214)\end{array}$ \\
\hline Percent of jobs in self-employment & $\begin{array}{r}-0.022 \\
(0.065)\end{array}$ & $\begin{array}{l}-0.400 * * * \\
(0.119)\end{array}$ & $\begin{array}{l}-0.385 * * * \\
(0.141)\end{array}$ & $\begin{array}{r}-0.219 \\
(0.232)\end{array}$ \\
\hline Housing price index growth & $\begin{array}{l}-0.054 * * * \\
(0.018)\end{array}$ & $\begin{array}{l}0.148 * * * \\
(0.039)\end{array}$ & $\begin{array}{l}0.102 * * \\
(0.043)\end{array}$ & $\begin{array}{l}-0.141 * \\
(0.081)\end{array}$ \\
\hline GSP per capita (log) & $\begin{array}{r}0.005 \\
(0.011)\end{array}$ & $\begin{array}{r}0.024 \\
(0.016)\end{array}$ & $\begin{array}{r}0.033 \\
(0.026)\end{array}$ & $\begin{array}{l}0.230 * * * \\
(0.042)\end{array}$ \\
\hline GSP growth (percent) & $\begin{array}{r}-0.072 \\
(0.053)\end{array}$ & $\begin{array}{r}-0.004 \\
(0.064)\end{array}$ & $\begin{array}{r}-0.039 \\
(0.067)\end{array}$ & $\begin{array}{l}-0.254 * \\
(0.133)\end{array}$ \\
\hline Great Recession indicator & $\begin{array}{r}0.002 \\
(0.046)\end{array}$ & $\begin{array}{r}-0.043 \\
(0.050)\end{array}$ & $\begin{array}{r}-0.152 \\
(0.106)\end{array}$ & $\begin{array}{l}-0.301 * * \\
(0.119)\end{array}$ \\
\hline Year dummies & Yes & Yes & Yes & Yes \\
\hline State dummies & Yes & Yes & Yes & Yes \\
\hline R squared & 0.251 & 0.393 & 0.575 & 0.463 \\
\hline Number of observations & 1533 & 1617 & 1648 & 1648 \\
\hline
\end{tabular}


Table 6.2. Relationship between High-educated Older Persons' Employment and High-educated Primeaged (Both Sexes) (cont'd)

\begin{tabular}{|c|c|c|c|c|}
\hline & $\mathrm{UE}$ & EMP & Hours worked $(\log )$ & Wage $(\log )$ \\
\hline Older persons' EMP rate & $\begin{array}{r}0.000 \\
(0.007)\end{array}$ & $\begin{array}{r}0.013 \\
(0.011)\end{array}$ & $\begin{array}{r}0.012 \\
(0.019)\end{array}$ & $\begin{array}{l}0.072 * * \\
(0.028)\end{array}$ \\
\hline Older persons' EMP rate $*$ Great Recession indicator & $\begin{array}{l}-0.039 * * \\
(0.018)\end{array}$ & $\begin{array}{l}0.151 * * * \\
(0.039)\end{array}$ & $\begin{array}{l}0.192 * * * \\
(0.048)\end{array}$ & $\begin{array}{l}0.181 * * \\
(0.085)\end{array}$ \\
\hline Local average wage of prime-aged & $\begin{array}{l}-0.008 \\
(0.005)\end{array}$ & $\begin{array}{r}0.004 \\
(0.014)\end{array}$ & $\begin{array}{r}-0.015 \\
(0.016)\end{array}$ & - \\
\hline Fraction of black in state & $\begin{array}{r}0.001 \\
(0.016)\end{array}$ & $\begin{array}{r}0.045 \\
(0.049)\end{array}$ & $\begin{array}{r}0.004 \\
(0.074)\end{array}$ & $\begin{array}{l}-0.330 * * \\
(0.151)\end{array}$ \\
\hline Fraction of less than high school in state & $\begin{array}{r}0.008 \\
(0.014)\end{array}$ & $\begin{array}{r}-0.017 \\
(0.039)\end{array}$ & $\begin{array}{r}-0.077 \\
(0.047)\end{array}$ & $\begin{array}{l}-0.274 * * * \\
(0.081)\end{array}$ \\
\hline Fraction of poor in state & $\begin{array}{l}0.087 * * * \\
(0.022)\end{array}$ & $\begin{array}{l}-0.157 * * * \\
(0.044)\end{array}$ & $\begin{array}{l}-0.108 * \\
(0.055)\end{array}$ & $\begin{array}{r}-0.005 \\
(0.104)\end{array}$ \\
\hline Percent of population $25-54$ & $\begin{array}{r}0.029 \\
(0.023)\end{array}$ & $\begin{array}{l}-0.053 \\
(0.047)\end{array}$ & $\begin{array}{l}-0.089 \\
(0.063)\end{array}$ & $\begin{array}{l}0.287 * * \\
(0.131)\end{array}$ \\
\hline State average unemployment rate & - & - & $\begin{array}{l}-0.281 * * * \\
(0.067)\end{array}$ & $\begin{array}{r}0.217 \\
(0.142)\end{array}$ \\
\hline Percent of jobs in manufacturing & $\begin{array}{l}-0.061 * * * \\
(0.016)\end{array}$ & $\begin{array}{l}0.142 * * \\
(0.054)\end{array}$ & $\begin{array}{r}-0.017 \\
(0.067)\end{array}$ & $\begin{array}{r}-0.197 \\
(0.133)\end{array}$ \\
\hline Percent of jobs in service industry & $\begin{array}{l}-0.006 \\
(0.019)\end{array}$ & $\begin{array}{r}0.051 \\
(0.037)\end{array}$ & $\begin{array}{l}-0.112 * \\
(0.059)\end{array}$ & $\begin{array}{r}0.063 \\
(0.132)\end{array}$ \\
\hline Percent of jobs in self-employment & $\begin{array}{r}-0.019 \\
(0.021)\end{array}$ & $\begin{array}{r}-0.102 \\
(0.064)\end{array}$ & $\begin{array}{r}-0.074 \\
(0.076)\end{array}$ & $\begin{array}{l}0.280 * * \\
(0.115)\end{array}$ \\
\hline Housing price index growth & $\begin{array}{l}-0.043 * * * \\
(0.008)\end{array}$ & $\begin{array}{r}0.021 \\
(0.019)\end{array}$ & $\begin{array}{r}-0.011 \\
(0.022)\end{array}$ & $\begin{array}{l}-0.103 * * \\
(0.040)\end{array}$ \\
\hline GSP per capita (log) & $\begin{array}{r}-0.002 \\
(0.004)\end{array}$ & $\begin{array}{r}0.009 \\
(0.011)\end{array}$ & $\begin{array}{r}0.007 \\
(0.018)\end{array}$ & $\begin{array}{l}0.186 * * * \\
(0.031)\end{array}$ \\
\hline GSP growth (percent) & $\begin{array}{l}-0.035 * * \\
(0.014)\end{array}$ & $\begin{array}{l}0.044 * \\
(0.024)\end{array}$ & $\begin{array}{r}-0.026 \\
(0.023)\end{array}$ & $\begin{array}{l}-0.109 * * \\
(0.050)\end{array}$ \\
\hline Great Recession indicator & $\begin{array}{r}0.023 \\
(0.016)\end{array}$ & $\begin{array}{l}-0.104 * * * \\
(0.026)\end{array}$ & $\begin{array}{l}-0.158 * * * \\
(0.035)\end{array}$ & $\begin{array}{r}-0.062 \\
(0.073)\end{array}$ \\
\hline Year dummies & Yes & Yes & Yes & Yes \\
\hline State dummies & Yes & Yes & Yes & Yes \\
\hline R squared & 0.557 & 0.629 & 0.664 & 0.874 \\
\hline Number of observations & 1614 & 1620 & 1648 & 1648 \\
\hline
\end{tabular}

Note: $*$ significant at $10 \%, * *$ significant at $5 \%, * * *$ significant at $1 \%$. All variables refer only to high-educated individuals. 
Table 7. Sensitivity Checks, U.S. Data

\begin{tabular}{|c|c|c|c|c|c|c|c|c|}
\hline \multirow[b]{2}{*}{ Older persons' employment rate } & \multicolumn{4}{|c|}{ Youth, both sexes } & \multicolumn{4}{|c|}{ Prime-aged, both sexes } \\
\hline & Unemployment & Employment & $\begin{array}{l}\text { Hours worked } \\
(\log )\end{array}$ & $\begin{array}{l}\text { Wage } \\
(\log )\end{array}$ & Unemployment & Employment & $\begin{array}{c}\text { Hours worked } \\
(\log )\end{array}$ & $\begin{array}{l}\text { Wage } \\
(\log )\end{array}$ \\
\hline \multirow[t]{2}{*}{ State-fixed effects } & -0.021 & $0.065 * *$ & 0.052 & 0.008 & -0.012 & $0.044 * * *$ & 0.022 & $0.078 * *$ \\
\hline & $(0.024)$ & $(0.032)$ & $(0.037)$ & $(0.073)$ & $(0.008)$ & $(0.015)$ & $(0.019)$ & $(0.034)$ \\
\hline \multirow[t]{2}{*}{ 3-year lag (state-fixed effects) } & -0.016 & 0.032 & 0.016 & $0.153 * *$ & $-0.020 * *$ & $0.031 *$ & 0.021 & $0.065 *$ \\
\hline & $(0.020)$ & $(0.034)$ & $(0.048)$ & $(0.071)$ & $(0.008)$ & $(0.018)$ & $(0.017)$ & $(0.037)$ \\
\hline \multirow[t]{2}{*}{ GLS (state-fixed effects) } & -0.021 & $0.089 * * *$ & $0.067 * *$ & 0.038 & $-0.018 * *$ & $0.045 * * *$ & 0.016 & 0.039 \\
\hline & $(0.020)$ & $(0.027)$ & $(0.033)$ & $(0.053)$ & $(0.007)$ & $(0.011)$ & $(0.013)$ & $(0.027)$ \\
\hline \multirow[t]{2}{*}{ Pooled three years (state-fixed effects) } & -0.056 & $0.222 * * *$ & 0.102 & 0.027 & -0.013 & $0.108 * * *$ & 0.047 & 0.068 \\
\hline & $(0.044)$ & $(0.054)$ & $(0.066)$ & $(0.122)$ & $(0.016)$ & $(0.025)$ & $(0.036)$ & $(0.043)$ \\
\hline & \multicolumn{4}{|c|}{ Youth male } & \multicolumn{4}{|c|}{ Prime-aged male } \\
\hline Older persons' employment rate & Unemployment & Employment & $\begin{array}{c}\text { Hours worked } \\
(\log )\end{array}$ & $\begin{array}{l}\text { Wage } \\
(\log )\end{array}$ & Unemployment & Employment & $\begin{array}{c}\text { Hours worked } \\
(\log )\end{array}$ & $\begin{array}{l}\text { Wage } \\
(\log )\end{array}$ \\
\hline \multirow[t]{2}{*}{ State-fixed effects } & -0.008 & 0.055 & $0.139 * * *$ & -0.012 & -0.012 & $0.024 * * *$ & $0.034 * *$ & 0.038 \\
\hline & $(0.030)$ & $(0.035)$ & $(0.050)$ & $(0.070)$ & $(0.008)$ & $(0.009)$ & $(0.014)$ & $(0.025)$ \\
\hline \multirow[t]{2}{*}{ 3-year lag (state-fixed effects) } & 0.015 & -0.004 & 0.014 & $0.105 *$ & $-0.015 *$ & 0.018 & 0.016 & $0.073 * *$ \\
\hline & $(0.026)$ & $(0.033)$ & $(0.048)$ & $(0.060)$ & $(0.008)$ & $(0.012)$ & $(0.014)$ & $(0.028)$ \\
\hline \multirow[t]{2}{*}{ GLS (state-fixed effects) } & -0.002 & $0.083 * * *$ & $0.079 * *$ & -0.038 & -0.010 & 0.020 & $0.022 * *$ & 0.023 \\
\hline & $(0.022)$ & $(0.028)$ & $(0.033)$ & $(0.051)$ & $(0.007)$ & $(0.009)$ & $(0.010)$ & $(0.024)$ \\
\hline \multirow[t]{2}{*}{ Pooled three years (state-fixed effects) } & -0.057 & $0.133 * *$ & $0.188 * * *$ & -0.001 & 0.000 & $0.053 * *$ & 0.037 & $0.100 * *$ \\
\hline & $(0.047)$ & $(0.063)$ & $(0.068)$ & $(0.114)$ & $(0.016)$ & $(0.020)$ & $(0.025)$ & $(0.004)$ \\
\hline
\end{tabular}


Table 7. Sensitivity Checks, U.S. Data (cont'd)

\begin{tabular}{|c|c|c|c|c|c|c|c|c|}
\hline \multirow[b]{2}{*}{ Older persons' employment rate } & \multicolumn{4}{|c|}{ Youth female } & \multicolumn{4}{|c|}{ Prime-aged female } \\
\hline & Unemployment & Employment & $\begin{array}{l}\text { Hours worked } \\
\text { (log) }\end{array}$ & $\begin{array}{l}\text { Wage } \\
(\log )\end{array}$ & Unemployment & Employment & $\begin{array}{l}\text { Hours worked } \\
(\log )\end{array}$ & $\begin{array}{l}\text { Wage } \\
\text { (log) }\end{array}$ \\
\hline \multirow[t]{2}{*}{ State-fixed effects } & -0.031 & 0.002 & -0.030 & -0.030 & 0.001 & $0.045 * *$ & $0.056 *$ & 0.014 \\
\hline & $(0.020)$ & $(0.034)$ & $(0.045)$ & $(0.070)$ & $(0.009)$ & $(0.051)$ & $(0.031)$ & $(0.035)$ \\
\hline \multirow[t]{2}{*}{ 3-year lag (state-fixed effects) } & $-0.044 *$ & $0.039 * *$ & -0.006 & 0.007 & $-0.017 * *$ & $0.055 * *$ & $0.091 * * *$ & 0.000 \\
\hline & $(0.019)$ & $(0.030)$ & $(0.035)$ & $(0.067)$ & $(0.007)$ & $(0.015)$ & $(0.027)$ & $(0.032)$ \\
\hline \multirow[t]{2}{*}{ GLS (state-fixed effects) } & $-0.046 * *$ & 0.013 & 0.001 & -0.003 & -0.005 & $0.054 * * *$ & $0.043 * *$ & 0.014 \\
\hline & $(0.018)$ & $(0.027)$ & $(0.036)$ & $(0.053)$ & $(0.006)$ & $(0.012)$ & $(0.017)$ & $(0.025)$ \\
\hline \multirow{2}{*}{ Pooled three years (state-fixed effects) } & -0.054 & $0.153 * * *$ & 0.048 & -0.055 & -0.006 & $0.124 * * *$ & $0.144 * *$ & -0.014 \\
\hline & $(0.040)$ & $(0.052)$ & $(0.081)$ & $(0.109)$ & $(0.012)$ & $(0.032)$ & $(0.056)$ & $(0.051)$ \\
\hline \multirow[t]{2}{*}{ GLS (state-fixed effects) } & \multicolumn{4}{|c|}{ Youth } & \multicolumn{4}{|c|}{ Prime-aged } \\
\hline & Unemployment & Employment & Hours worked & Wage & Unemployment & Employment & Hours worked & Wage \\
\hline \multirow[t]{2}{*}{ Elderly employment rate } & $-0.021 * * *$ & $0.089 * * *$ & $0.067 * *$ & 0.038 & -0.018 & $0.045 * * *$ & 0.016 & 0.039 \\
\hline & $(0.020)$ & $(0.027)$ & $(0.033)$ & $(0.053)$ & $(0.007)$ & $(0.011)$ & $(0.013)$ & $(0.027)$ \\
\hline \multirow[t]{2}{*}{ Elderly LFP Male } & -0.002 & $0.083 * * *$ & $0.079 * *$ & -0.038 & -0.010 & 0.020 & $0.022 * *$ & 0.023 \\
\hline & $(0.022)$ & $(0.028)$ & $(0.033)$ & $(0.051)$ & $(0.007)$ & $(0.009)$ & $(0.010)$ & $(0.024)$ \\
\hline \multirow[t]{2}{*}{ Elderly LFP Female } & $-0.046 * *$ & 0.013 & 0.001 & -0.003 & -0.005 & $0.054 * * *$ & $0.043 * *$ & 0.014 \\
\hline & $(0.018)$ & $(0.027)$ & $(0.036)$ & $(0.053)$ & $(0.006)$ & $(0.012)$ & $(0.017)$ & $(0.025)$ \\
\hline
\end{tabular}


Table 8. Impact of Older Persons' Employment on Labor Market Outcomes for the Young and the Prime-aged, U.S. Data, TSLS

\begin{tabular}{|c|c|c|c|c|c|c|c|c|}
\hline \multirow{2}{*}{$\begin{array}{l}\text { Panel A: } \\
\text { Outcome variable }\end{array}$} & \multicolumn{4}{|c|}{ Youth, both sexes } & \multicolumn{4}{|c|}{ Prime-aged, both sexes } \\
\hline & OLS & IV & First stage & F-statistic & OLS & IV & First stage & F-statistic \\
\hline Unemployment & $\begin{array}{l}-0.008 \\
(0.026)\end{array}$ & $\begin{array}{r}0.085 \\
(0.199)\end{array}$ & $\begin{array}{l}-0.085 * * * \\
(0.021)\end{array}$ & 16.76 & $\begin{array}{l}-0.006 \\
(0.009)\end{array}$ & $\begin{array}{l}-0.023 \\
(0.058)\end{array}$ & $\begin{array}{l}-0.108 * * * \\
(0.022)\end{array}$ & 23.37 \\
\hline Employment & $\begin{array}{l}0.063 * \\
(0.032)\end{array}$ & $\begin{array}{r}-0.231 \\
(0.300)\end{array}$ & $\begin{array}{l}-0.080 * * * \\
(0.021)\end{array}$ & 14.76 & $\begin{array}{l}0.036 * * * \\
(0.013)\end{array}$ & $\begin{array}{l}0.397 * * * \\
(0.121)\end{array}$ & $\begin{array}{l}-0.104 * * * \\
(0.022)\end{array}$ & 21.51 \\
\hline Hours worked & $\begin{array}{r}0.056 \\
(0.038)\end{array}$ & $\begin{array}{r}-0.328 \\
(0.355)\end{array}$ & $\begin{array}{l}-0.086 * * * \\
(0.021)\end{array}$ & 17.45 & $\begin{array}{r}0.011 \\
(0.017)\end{array}$ & $\begin{array}{l}0.302 * * \\
(0.126)\end{array}$ & $\begin{array}{l}-0.107 * * * \\
(0.022)\end{array}$ & 23.28 \\
\hline Wage rate & $\begin{array}{r}-0.031 \\
(0.074) \\
\end{array}$ & $\begin{array}{r}0.822 \\
(0.605) \\
\end{array}$ & $\begin{array}{l}-0.086 * * * \\
(0.021) \\
\end{array}$ & 17.28 & $\begin{array}{l}0.083 * * * \\
(0.030)\end{array}$ & $\begin{array}{r}0.245 \\
(0.240) \\
\end{array}$ & $\begin{array}{l}-0.109 * * * \\
(0.022)\end{array}$ & 23.85 \\
\hline Panel B: & \multicolumn{4}{|c|}{ Youth male } & \multicolumn{4}{|c|}{ Prime-aged male } \\
\hline Outcome variable & OLS & IV & First stage & F-statistic & OLS & IV & First stage & F-statistic \\
\hline Unemployment & $\begin{array}{l}-0.009 \\
(0.026)\end{array}$ & $\begin{array}{l}-0.277 \\
(0.299)\end{array}$ & $\begin{array}{l}-0.084 * * * \\
(0.028)\end{array}$ & 8.78 & $\begin{array}{l}-0.005 \\
(0.008)\end{array}$ & $\begin{array}{l}-0.079 \\
(0.065)\end{array}$ & $\begin{array}{l}-0.131 * * * \\
(0.031)\end{array}$ & 18.33 \\
\hline Employment & $\begin{array}{r}0.064 \\
(0.041)\end{array}$ & $\begin{array}{r}-0.281 \\
(0.329)\end{array}$ & $\begin{array}{l}-0.098 * * * \\
(0.028)\end{array}$ & 11.94 & $\begin{array}{l}0.018 * \\
(0.009)\end{array}$ & $\begin{array}{l}0.344 * * * \\
(0.120)\end{array}$ & $\begin{array}{l}-0.126 * * * \\
(0.030)\end{array}$ & 17.25 \\
\hline Hours worked & $\begin{array}{l}0.134 * * \\
(0.051)\end{array}$ & $\begin{array}{l}-0.862 * \\
(0.488)\end{array}$ & $\begin{array}{l}-0.096 * * * \\
(0.028)\end{array}$ & 11.80 & $\begin{array}{l}0.027 * \\
(0.014)\end{array}$ & $\begin{array}{r}-0.030 \\
(0.111)\end{array}$ & $\begin{array}{l}-0.123 * * * \\
(0.030)\end{array}$ & 16.42 \\
\hline Wage rate & $\begin{array}{r}-0.029 \\
(0.068) \\
\end{array}$ & $\begin{array}{r}0.887 \\
(0.705) \\
\end{array}$ & $\begin{array}{l}-0.096 * * * \\
(0.028)\end{array}$ & 11.68 & $\begin{array}{r}0.048 * \\
(0.025) \\
\end{array}$ & $\begin{array}{r}0.231 \\
(0.253) \\
\end{array}$ & $\begin{array}{l}-0.124 * * * \\
(0.030)\end{array}$ & 16.72 \\
\hline Panel C: & \multicolumn{4}{|c|}{ Youth female } & \multicolumn{4}{|c|}{ Prime-aged female } \\
\hline Outcome variable & OLS & IV & First stage & F-statistic & OLS & IV & First stage & F-statistic \\
\hline Unemployment & $\begin{array}{l}-0.045 * * \\
(0.022)\end{array}$ & $\begin{array}{r}0.351 \\
(0.438)\end{array}$ & $\begin{array}{l}-0.051 * \\
(0.028)\end{array}$ & 3.43 & $\begin{array}{l}-0.002 \\
(0.009)\end{array}$ & $\begin{array}{r}0.017 \\
(0.086)\end{array}$ & $\begin{array}{l}-0.081 * * * \\
(0.030)\end{array}$ & 7.33 \\
\hline Employment & $\begin{array}{r}0.006 \\
(0.034)\end{array}$ & $\begin{array}{r}-0.389 \\
(0.620)\end{array}$ & $\begin{array}{l}-0.051 * \\
(0.027)\end{array}$ & 3.45 & $\begin{array}{l}0.048 * * \\
(0.018)\end{array}$ & $\begin{array}{c}0.530 * \\
(0.300)\end{array}$ & $\begin{array}{l}-0.067 * * \\
(0.030)\end{array}$ & 5.09 \\
\hline Hours worked & $\begin{array}{r}-0.025 \\
(0.046)\end{array}$ & $\begin{array}{r}-0.247 \\
(0.838)\end{array}$ & $\begin{array}{l}-0.050 * \\
(0.027)\end{array}$ & 3.34 & $\begin{array}{l}0.056 * \\
(0.029)\end{array}$ & $\begin{array}{l}1.210 * * \\
(0.590)\end{array}$ & $\begin{array}{l}-0.066 * * \\
(0.030)\end{array}$ & 5.06 \\
\hline Wage rate & $\begin{array}{r}-0.038 \\
(0.068)\end{array}$ & $\begin{array}{r}-0.114 \\
(1.300)\end{array}$ & $\begin{array}{l}-0.050 * \\
(0.027)\end{array}$ & 3.35 & $\begin{array}{r}0.019 \\
(0.028)\end{array}$ & $\begin{array}{r}0.194 \\
(0.502)\end{array}$ & $\begin{array}{l}-0.067 * * \\
(0.029)\end{array}$ & 5.10 \\
\hline
\end{tabular}

Note: $*$ significant at $10 \%, * *$ significant at $5 \%, * * *$ significant at $1 \%$. 
Table 9. Labor Force Participation Rates in China, by Age Groups and by Province Labor force participation rates of older persons

\begin{tabular}{lrrr} 
& 1990 & 2000 & 2005 \\
\hline 10th percentile & 0.36 & 0.30 & 0.31 \\
25th percentile & 0.38 & 0.34 & 0.35 \\
50th percentile & 0.40 & 0.38 & 0.46 \\
90th percentile & 0.53 & 0.48 & 0.53
\end{tabular}

Labor force participation rates of the young

\begin{tabular}{lccc} 
& 1990 & 2000 & 2005 \\
\hline 10th percentile & 0.68 & 0.66 & 0.53 \\
25th percentile & 0.70 & 0.70 & 0.57 \\
50th percentile & 0.76 & 0.74 & 0.61 \\
90th percentile & 0.84 & 0.84 & 0.76
\end{tabular}

Labor force participation rates of the prime-aged

\begin{tabular}{lrrr} 
& 1990 & 2000 & 2005 \\
\hline 10th percentile & 0.74 & 0.79 & 0.76 \\
25th percentile & 0.81 & 0.82 & 0.79 \\
50th percentile & 0.88 & 0.85 & 0.82 \\
90th percentile & 0.94 & 0.90 & 0.87
\end{tabular}


Table 10. Descriptive Statistics, China Data, by Province

\begin{tabular}{|c|c|c|c|c|c|}
\hline & \multicolumn{4}{|c|}{ Between province over time } & \multirow{2}{*}{$\begin{array}{c}\begin{array}{c}\text { Within- } \\
\text { province over } \\
\text { time }\end{array} \\
\begin{array}{c}\text { Standard } \\
\text { deviation }\end{array} \\
\end{array}$} \\
\hline & Mean & $\begin{array}{c}\text { Standard } \\
\text { deviation }\end{array}$ & Min & $\operatorname{Max}$ & \\
\hline \multicolumn{6}{|l|}{ Dependent variables } \\
\hline \multicolumn{6}{|l|}{ All Young } \\
\hline Labor force participation rate & 0.717 & 0.061 & 0.608 & 0.826 & 0.066 \\
\hline Unemployment rate & 0.103 & 0.046 & 0.036 & 0.248 & 0.033 \\
\hline Employment rate & 0.636 & 0.083 & 0.490 & 0.798 & 0.065 \\
\hline \multicolumn{6}{|l|}{ All Prime Age } \\
\hline Labor force participation rate & 0.845 & 0.055 & 0.716 & 0.920 & 0.034 \\
\hline Unemployment rate & 0.046 & 0.018 & 0.020 & 0.098 & 0.029 \\
\hline Employment rate & 0.804 & 0.058 & 0.675 & 0.903 & 0.047 \\
\hline \multicolumn{6}{|l|}{ Male Young } \\
\hline Labor force participation rate & 0.773 & 0.061 & 0.657 & 0.902 & 0.062 \\
\hline Unemployment rate & 0.099 & 0.048 & 0.034 & 0.278 & 0.037 \\
\hline Employment rate & 0.692 & 0.084 & 0.491 & 0.872 & 0.066 \\
\hline \multicolumn{6}{|l|}{ Male Prime Age } \\
\hline Labor force participation rate & 0.947 & 0.015 & 0.914 & 0.972 & 0.025 \\
\hline Unemployment rate & 0.043 & 0.016 & 0.020 & 0.081 & 0.031 \\
\hline Employment rate & 0.908 & 0.026 & 0.848 & 0.952 & 0.040 \\
\hline \multicolumn{6}{|l|}{ Female Young } \\
\hline Labor force participation rate & 0.664 & 0.090 & 0.512 & 0.836 & 0.077 \\
\hline Unemployment rate & 0.110 & 0.047 & 0.032 & 0.219 & 0.031 \\
\hline Employment rate & 0.582 & 0.104 & 0.394 & 0.789 & 0.069 \\
\hline \multicolumn{6}{|l|}{ Female Prime Age } \\
\hline Labor force participation rate & 0.717 & 0.110 & 0.436 & 0.880 & 0.050 \\
\hline Unemployment rate & 0.052 & 0.025 & 0.011 & 0.133 & 0.032 \\
\hline Employment rate & 0.675 & 0.106 & 0.426 & 0.843 & 0.065 \\
\hline \multicolumn{6}{|l|}{ Independent variables } \\
\hline \multicolumn{6}{|l|}{ All Older Persons } \\
\hline Employment rate & 0.384 & 0.065 & 0.199 & 0.505 & 0.049 \\
\hline Labor force participation rate & 0.407 & 0.072 & 0.202 & 0.537 & 0.041 \\
\hline \multicolumn{6}{|l|}{ Male Older Persons (50-64) } \\
\hline Employment rate & 0.510 & 0.080 & 0.293 & 0.686 & 0.064 \\
\hline Labor force participation rate & 0.528 & 0.085 & 0.294 & 0.695 & 0.059 \\
\hline
\end{tabular}




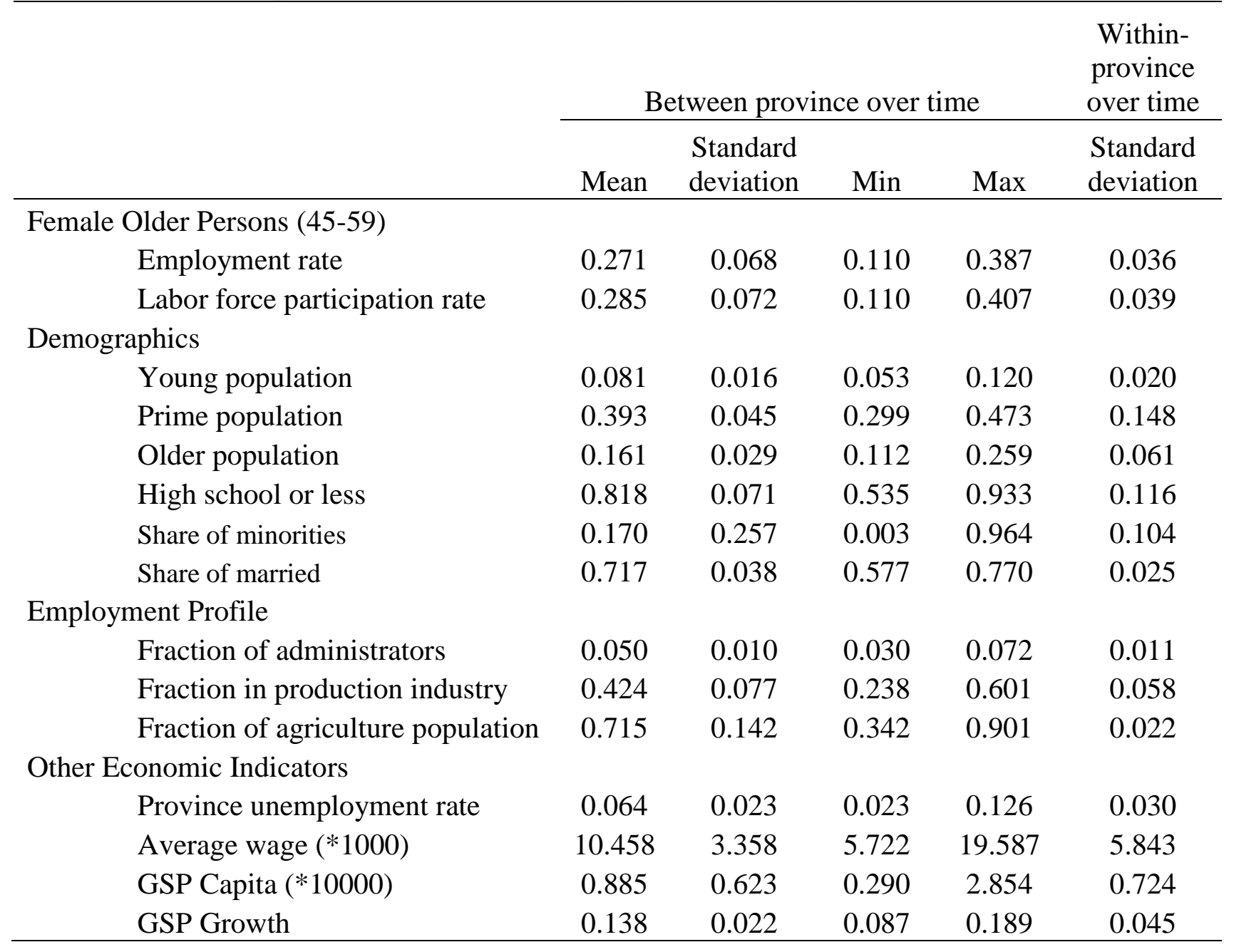


Table 11. Relationship between Older Persons' Employment and Youth Unemployment and Employment, China Data (Both Sexes)

\begin{tabular}{lll}
\hline & Unemployment & Employment \\
\hline Older persons' employment & 0.049 & 0.240 \\
Local average wage & $(0.093)$ & $(0.251)$ \\
& $-0.005^{*}$ & -0.002 \\
High school or less & $(0.003)$ & $(0.006)$ \\
& 0.027 & 0.070 \\
Province unemployment rate & $(0.027)$ & $(0.059)$ \\
& $1.224^{* * *}$ & -0.629 \\
Share of young population & $(0.227)$ & $(0.477)$ \\
Fraction of production workers & $-0.478^{* *}$ & 0.331 \\
& $(0.206)$ & $(0.644)$ \\
Fraction of administrator & -0.072 & 0.578 \\
& $(0.139)$ & $(0.411)$ \\
Fraction of Agriculture Population & 0.286 & 0.196 \\
& $(0.496)$ & $(1.348)$ \\
Share of minorities & -0.086 & 0.738 \\
& $(0.174)$ & $(0.557)$ \\
Share of married & 0.037 & 0.023 \\
& $(0.041)$ & $(0.087)$ \\
GSP per capita & -0.137 & 0.195 \\
& $(0.252)$ & $(0.682)$ \\
GSP growth & -0.006 & 0.064 \\
& $(0.018)$ & $(0.044)$ \\
Province dummies & -0.107 & -0.106 \\
Year dummies & $(0.074)$ & $(0.298)$ \\
R squared & Yes & Yes \\
\hline Number of observations & Yes & Yes \\
& 0.950 & 0.895 \\
\hline
\end{tabular}


Table 11. Relationship between Older Persons' Employment and Prime-aged Unemployment and Employment, China Data (Both Sexes) (cont'd)

\begin{tabular}{|c|c|c|}
\hline & Unemployment & Employment \\
\hline \multirow[t]{2}{*}{ Older persons' employment } & -0.088 & $0.396 * * *$ \\
\hline & $(0.076)$ & $(0.125)$ \\
\hline \multirow[t]{2}{*}{ Average wage } & 0.000 & 0.003 \\
\hline & $(0.002)$ & $(0.004)$ \\
\hline \multirow[t]{2}{*}{ High school or less } & 0.003 & 0.029 \\
\hline & $(0.016)$ & $(0.039)$ \\
\hline \multirow[t]{2}{*}{ Province unemployment rate } & $0.423 * * *$ & -0.324 \\
\hline & $(0.151)$ & $(0.299)$ \\
\hline \multirow[t]{2}{*}{ Share of prime-aged population } & -0.071 & 0.045 \\
\hline & $(0.065)$ & $(0.170)$ \\
\hline \multirow[t]{2}{*}{ Fraction of production workers } & -0.035 & 0.208 \\
\hline & $(0.111)$ & $(0.231)$ \\
\hline \multirow[t]{2}{*}{ Fraction of administrator } & -0.091 & 1.215 \\
\hline & $(0.311)$ & $(0.748)$ \\
\hline \multirow[t]{2}{*}{ Fraction of agriculture population } & -0.016 & 0.099 \\
\hline & $(0.149)$ & $(0.346)$ \\
\hline \multirow[t]{2}{*}{ Share of minorities } & $-0.028 *$ & 0.003 \\
\hline & $(0.014)$ & $(0.034)$ \\
\hline \multirow[t]{2}{*}{ Share of married } & 0.002 & $-0.656 * *$ \\
\hline & $(0.160)$ & $(0.313)$ \\
\hline \multirow[t]{2}{*}{ GSP per capita } & -0.025 & -0.011 \\
\hline & $(0.016)$ & $(0.032)$ \\
\hline \multirow[t]{2}{*}{ GSP growth } & 0.055 & -0.147 \\
\hline & 0.076 & $(0.145)$ \\
\hline State dummies & Yes & Yes \\
\hline Year dummies & Yes & Yes \\
\hline R squared & 0.930 & 0.936 \\
\hline Number of observations & 79 & 83 \\
\hline
\end{tabular}


Table 12. Relationship between Older Persons' Employment and Youth and Prime-aged Unemployment and Employment, China Data (by Gender)

\begin{tabular}{lll}
\hline & Unemployment & Employment \\
\hline Young male & 0.002 & 0.168 \\
& $(0.077)$ & $(0.298)$ \\
Prime-aged male & -0.056 & $0.173^{*}$ \\
& $(0.078)$ & $(0.098)$ \\
Young female & -0.077 & $0.681^{*}$ \\
& $(0.109)$ & $(0.337)$ \\
Prime-aged female & -0.154 & $0.913^{* * *}$ \\
& $(0.099)$ & $(0.249)$ \\
\hline
\end{tabular}

Note: * significant at $10 \%, * *$ significant at $5 \%, * * *$ significant at $1 \%$. 
Table 13. Impact of Older Persons' Employment on Labor Market Outcomes for the Young and the Prime-aged, China Data, Province Level, TSLS

\begin{tabular}{|c|c|c|c|c|c|c|c|c|}
\hline \multirow{2}{*}{$\begin{array}{l}\text { Panel A: } \\
\text { Outcome variable }\end{array}$} & \multicolumn{2}{|c|}{ Young, both sexes } & \multicolumn{6}{|c|}{ Prime-aged, both sexes } \\
\hline & OLS & IV & $\begin{array}{l}\text { First } \\
\text { stage }\end{array}$ & F-statistic & OLS & IV & $\begin{array}{l}\text { First } \\
\text { stage }\end{array}$ & F-statistic \\
\hline Unemployment & $\begin{array}{l}0.049 \\
(0.093)\end{array}$ & $\begin{array}{l}-0.096 \\
(0.136)\end{array}$ & $\begin{array}{l}-0.724 * * \\
(0.288)\end{array}$ & 6.299 & $\begin{array}{l}-0.088 \\
(0.076)\end{array}$ & $\begin{array}{l}0.030 \\
(0.104)\end{array}$ & $\begin{array}{l}-0.660 * * \\
(0.275)\end{array}$ & 5.782 \\
\hline Employment & $\begin{array}{l}0.240 \\
(0.251)\end{array}$ & $\begin{array}{l}0.891 * * \\
(0.367)\end{array}$ & $\begin{array}{l}-0.760 * * \\
(0.306)\end{array}$ & 6.149 & $\begin{array}{l}0.396 * * * \\
(0.125)\end{array}$ & $\begin{array}{l}0.375 * * \\
(0.178)\end{array}$ & $\begin{array}{l}-0.705^{* *} \\
(0.293)\end{array}$ & 5.804 \\
\hline Panel B: & \multicolumn{4}{|c|}{ Young male } & \multicolumn{4}{|c|}{ Prime-aged male } \\
\hline Outcome variable & OLS & IV & $\begin{array}{l}\text { First } \\
\text { stage }\end{array}$ & F-statistic & OLS & IV & $\begin{array}{l}\text { First } \\
\text { stage }\end{array}$ & F-statistic \\
\hline Unemployment & $\begin{array}{l}0.002 \\
(0.077)\end{array}$ & $\begin{array}{l}-0.288 * \\
(0.170)\end{array}$ & $\begin{array}{l}-0.717 * * \\
(0.301)\end{array}$ & 5.689 & $\begin{array}{l}-0.056 \\
(0.078)\end{array}$ & $\begin{array}{l}-0.036 \\
(0.121)\end{array}$ & $\begin{array}{l}-0.686^{* *} \\
(0.288)\end{array}$ & 5.663 \\
\hline Employment & $\begin{array}{l}0.168 \\
(0.298) \\
\end{array}$ & $\begin{array}{l}0.406 \\
(0.369)\end{array}$ & $\begin{array}{l}-0.828 * * \\
(0.313)\end{array}$ & 6.999 & $\begin{array}{l}0.173^{*} \\
(0.098)\end{array}$ & $\begin{array}{l}0.012 \\
(0.114)\end{array}$ & $\begin{array}{l}-0.806^{* *} \\
(0.302)\end{array}$ & 7.148 \\
\hline Panel C: & \multicolumn{4}{|c|}{ Young female } & \multicolumn{4}{|c|}{ Prime-aged female } \\
\hline Outcome variable & OLS & IV & $\begin{array}{l}\text { First } \\
\text { stage }\end{array}$ & F-statistic & OLS & IV & $\begin{array}{l}\text { First } \\
\text { stage }\end{array}$ & F-statistic \\
\hline Unemployment & $\begin{array}{l}-0.077 \\
(0.109)\end{array}$ & $\begin{array}{l}-0.046 \\
(0.172)\end{array}$ & $\begin{array}{l}-0.512 * * \\
(0.221)\end{array}$ & 5.345 & $\begin{array}{l}-0.154 \\
(0.099)\end{array}$ & $\begin{array}{l}0.002 \\
(0.147)\end{array}$ & $\begin{array}{l}-0.466^{* *} \\
(0.212)\end{array}$ & 4.853 \\
\hline Employment & $\begin{array}{l}0.681 * \\
(0.337)\end{array}$ & $\begin{array}{l}1.066 * * \\
(0.426)\end{array}$ & $\begin{array}{l}-0.499 * * \\
(0.238)\end{array}$ & 4.382 & $\begin{array}{l}0.913 * * * \\
(0.249)\end{array}$ & $\begin{array}{l}0.840 * * \\
(0.380)\end{array}$ & $\begin{array}{l}-0.460 * \\
(0.228)\end{array}$ & 4.057 \\
\hline
\end{tabular}

Note: $*$ significant at $10 \%, * *$ significant at $5 \%, * * *$ significant at $1 \%$. 
Table 14. Impact of Older Persons' Employment on Labor Market Outcomes for the Young and the Prime-aged, China Data, Prefecture Level, TSLS

\begin{tabular}{|c|c|c|c|c|c|c|}
\hline Panel A: & $\begin{array}{c}\text { Young, } \\
\text { both sexes }\end{array}$ & $\begin{array}{c}\text { Prime, } \\
\text { both sexes }\end{array}$ & $\begin{array}{l}\text { Young } \\
\text { male }\end{array}$ & $\begin{array}{c}\text { Prime-aged } \\
\text { male }\end{array}$ & $\begin{array}{l}\text { Young } \\
\text { female }\end{array}$ & $\begin{array}{c}\text { Prime-aged } \\
\text { female }\end{array}$ \\
\hline $\begin{array}{l}\text { Outcome } \\
\text { variable }\end{array}$ & \multicolumn{6}{|c|}{ Employment (all education groups) } \\
\hline \multirow[t]{2}{*}{ OLS } & $0.210 * *$ & $0.335 * * *$ & 0.065 & 0.094 & $0.456 * * *$ & $0.828 * * *$ \\
\hline & 0.080 & $(0.052)$ & $(0.059)$ & $(0.088)$ & $(0.088)$ & $(0.093)$ \\
\hline \multirow[t]{2}{*}{ IV } & 0.148 & -0.227 & -1.16 & -0.443 & -0.112 & -1.457 \\
\hline & $(0.561)$ & $(0.392)$ & $(0.854)$ & $(0.564)$ & $(0.613)$ & $(0.922)$ \\
\hline \multirow[t]{2}{*}{ First stage } & $-0.279 * *$ & $-0.299 * *$ & $-0.241 * *$ & $-0.295 * *$ & $-0.306 * *$ & $-0.316 * * *$ \\
\hline & $(0.393)$ & $(0.117)$ & $(0.118)$ & $(0.119)$ & $(0.119)$ & $(0.117)$ \\
\hline F-statistic & 5.514 & 6.590 & 4.206 & 6.088 & 6.553 & 7.351 \\
\hline $\mathrm{N}$ & 341 & 340 & 340 & 340 & 340 & 340 \\
\hline \multirow{2}{*}{$\begin{array}{l}\text { Panel B: } \\
\text { Outcome } \\
\text { variable }\end{array}$} & $\begin{array}{c}\text { Young, } \\
\text { both sexes }\end{array}$ & $\begin{array}{c}\text { Prime, } \\
\text { both sexes }\end{array}$ & $\begin{array}{l}\text { Young } \\
\text { male }\end{array}$ & $\begin{array}{c}\text { Prime-aged } \\
\text { male }\end{array}$ & $\begin{array}{l}\text { Young } \\
\text { female }\end{array}$ & $\begin{array}{c}\text { Prime-aged } \\
\text { female }\end{array}$ \\
\hline & \multicolumn{6}{|c|}{ Employment (low-education group) } \\
\hline \multirow[t]{2}{*}{ OLS } & 0.210 & 0.335 & 0.125 & $0.087 * * *$ & $0.456 * * *$ & $0.828 * * *$ \\
\hline & $(0.080)$ & $(0.052)$ & $(0.081)$ & $(0.018)$ & $(0.088)$ & $(0.093)$ \\
\hline \multirow[t]{2}{*}{ IV } & 0.148 & -0.227 & -0.067 & 0.157 & -0.112 & -1.457 \\
\hline & $(0.561)$ & $(0.392)$ & $(0.661)$ & $(0.097)$ & $(0.613)$ & $(0.922)$ \\
\hline \multirow[t]{2}{*}{ First stage } & $-0.279 * *$ & $-0.299 * *$ & $-0.247 * *$ & $-0.314 * * *$ & $-0.306^{* *}$ & $-0.316 * * *$ \\
\hline & $(0.119)$ & $(0.117)$ & $(0.124)$ & $(0.118)$ & $(0.119)$ & $(0.117)$ \\
\hline F-statistic & 5.514 & 6.590 & 3.942 & 7.161 & 6.553 & 7.351 \\
\hline $\mathrm{N}$ & 341 & 340 & 340 & 340 & 340 & 340 \\
\hline
\end{tabular}

Note: $*$ significant at $10 \%, * *$ significant at $5 \%, * * *$ significant at $1 \%$. 
Appendix Table 1. Correlation of Older Persons' Employment with Youth and PrimeAged Labor Market Activity (With vs. Without Wage Control)

\begin{tabular}{lcccc}
\hline & $\begin{array}{l}\text { Unemployment (with } \\
\text { wage control) }\end{array}$ & $\begin{array}{l}\text { Unemployment } \\
\text { (without wage control) }\end{array}$ & $\begin{array}{c}\text { Employment (with control) } \\
\text { wage }\end{array}$ & $\begin{array}{l}\text { Employment } \\
\text { (without wage control) }\end{array}$ \\
\hline Youth, both sexes & -0.021 & -0.021 & $0.065 * *$ & $0.065 * *$ \\
prime-aged, both sexes & -0.01191 & $(0.024)$ & $(0.032)$ & $(0.032)$ \\
& $(0.009)$ & -0.011 & $0.044 * * *$ & $0.041 * * *$ \\
Youth, male & -0.018 & $(0.009)$ & $(0.015)$ & $(0.015)$ \\
prime-aged, male & $(0.028)$ & -0.018 & 0.061 & 0.061 \\
& -0.012 & $(0.028)$ & $(0.037)$ & $(0.037)$ \\
Youth, female & $(0.007)$ & -0.009 & $0.027 * * *$ & $0.027 * * *$ \\
& -0.037 & $(0.007)$ & $(0.009)$ & $(0.009)$ \\
Prime-aged, female & $(0.021)$ & $-0.037 *$ & 0.008 & 0.008 \\
& -0.001 & $(0.021)$ & $(0.033)$ & $(0.033)$ \\
& $(0.008)$ & $(0.008)$ & $0.045 * *$ & $0.045 * *$ \\
\hline
\end{tabular}

Appendix Table 2. Reduced-form Estimation of Elderly Mortality on Young/Prime-age Labor Supply

\begin{tabular}{lrr}
\hline Elderly mortality & Unemployment & Employment \\
\cline { 2 - 3 } & & \\
\hline Youth & -0.008 & 0.021 \\
& $(0.021)$ & $(0.036)$ \\
Prime-aged & 0.034 & -0.074 \\
& $(0.051)$ & $(0.055)$ \\
\hline
\end{tabular}


Appendix Table 3. Labor Force Participation Rates by Age Groups, China Data, by Prefecture

Labor force participation rates of the older workers

\begin{tabular}{lc} 
& 1990 \\
\hline 10th percentile & 0.22 \\
25th percentile & 0.29 \\
50th percentile & 0.38 \\
90th percentile & 0.54
\end{tabular}

Labor force participation rates of the young

\begin{tabular}{lc} 
& 1990 \\
\hline 10th percentile & 0.58 \\
25th percentile & 0.69 \\
50th percentile & 0.80 \\
90th percentile & 0.92
\end{tabular}

Labor force participation rates of the prime-aged

\begin{tabular}{lc} 
& 1990 \\
\hline 10th percentile & 0.66 \\
25th percentile & 0.80 \\
50th percentile & 0.89 \\
90th percentile & 0.96
\end{tabular}




\section{RECENT WORKING PAPERS FROM THE \\ CENTER FOR RETIREMENT RESEARCH AT BOSTON COLLEGE}

Growth in Health Consumption and Its Implications for Financing OASDI: An International Perspective

Barry P. Bosworth and Gary Burtless, September 2012

Using Participant Data to Improve 401(k) Asset Allocation

Zhenyu Li and Anthony Webb, September 2012

Job Demand and Early Retirement

Sepideh Modrek and Mark R. Cullen, August 2012

Changes in Labor Force Participation of Older Americans and Their Pension Structures: A Policy Perspective

Frank W. Heiland and Zhe Li, July 2012

How Would GASB Proposals Affect State and Local Pension Reporting?

Alicia H. Munnell, Jean-Pierre Aubry, Joshua Hurwitz and Laura Quinby, June 2012

Borrow Less Tomorrow: Behavioral Approaches to Debt Reduction

Dean Karlan and Jonathan Zinman, May 2012

Spousal Labor Market Effects from Government Health Insurance: Evidence from A Veterans Affairs Expansion

Melissa A. Boyle and Joanna N. Lahey, April 2012

Measuring Social Security Proposals by More than Solvency: Impacts on Poverty, Progressivity, Horizontal Equity, and Work Incentives

Melissa M. Favreault and C. Eugene Steuerle, April 2012

How Important Is Asset Allocation to Financial Security in Retirement?

Alicia H. Munnell, Natalia Sergeyevna Orlova, and Anthony Webb, April 2012

Great Recession-Induced Early Claimers: Who Are They? How Much Do They Lose?

Matthew S. Rutledge and Norma B. Coe, April 2012

Effects of Employer Health Costs on the Trend and Distribution of Social Security-Taxable Wages

Gary Burtless And Sveta Milusheva, April 2012

Should Households Base Asset Decumulation Strategies on Required Minimum Distribution Tables?

Wei Sun and Anthony Webb, April 2012

All working papers are available on the Center for Retirement Research website (http://crr.bc.edu) and can be requested by e-mail (crr@bc.edu) or phone (617-552-1762). 